\title{
Profiling Dust Mass Concentration in Northwest China Using a Joint Lidar and Sun-Photometer Setting
}

\author{
Tianhe Wang ${ }^{1}{ }^{(}$, Ying Han ${ }^{1}$, Wenli Hua ${ }^{1,2}$, Jingyi Tang ${ }^{1}$, Jianping Huang ${ }^{1, *}$, Tian Zhou ${ }^{1}$, Zhongwei Huang ${ }^{1}$, \\ Jianrong $\mathrm{Bi}^{1}$ and Hailing $\mathrm{Xie}^{3}$
}

1 Key Laboratory for Semi-Arid Climate Change of the Ministry of Education, College of Atmospheric Sciences, Lanzhou University, Lanzhou 730000, China; wangth@lzu.edu.cn (T.W.); hany16@lzu.edu.cn (Y.H.); hwljn@163.com (W.H.); tangjy19@lzu.edu.cn (J.T.); zhoutian@lzu.edu.cn (T.Z.); huangzhongwei@lzu.edu.cn (Z.H.); bij@@lzu.edu.cn (J.B.)

2 Department of Atmospheric and Oceanic Sciences, Fudan University, Shanghai 200000, China

3 Department of Atmospheric and Oceanic Sciences, University of Colorado, Boulder, CO 80309, USA; Hailing.Xie@colorado.edu

* Correspondence: hjp@lzu.edu.cn

Citation: Wang, T.; Han, Y.; Hua, W.; Tang, J.; Huang, J.; Zhou, T.; Huang, Z.; Bi, J.; Xie, H. Profiling Dust Mass Concentration in Northwest China Using a Joint Lidar and Sun-Photometer Setting. Remote Sens. 2021, 13, 1099. https://doi.org/ $10.3390 /$ rs13061099

Academic Editor: Wei Gong

Received: 19 February 2021

Accepted: 12 March 2021

Published: 13 March 2021

Publisher's Note: MDPI stays neutral with regard to jurisdictional claims in published maps and institutional affiliations.

Copyright: (c) 2021 by the authors. Licensee MDPI, Basel, Switzerland. This article is an open access article distributed under the terms and conditions of the Creative Commons Attribution (CC BY) license (https:// creativecommons.org/licenses/by/ $4.0 /)$.

\begin{abstract}
The satellite-based estimation of the dust mass concentration (DMC) is essential for accurately evaluating the global biogeochemical cycle of the dust aerosols. As for the uncertainties in estimating DMC caused by mixing dust and pollutants and assuming a fixed value for the mass extinction efficiency (MEE), a classic lidar-photometer method is employed to identify and separate the dust from pollutants, obtain the dust MEE, and evaluate the effect of the above uncertainties, during five dust field experiments in Northwest China. Our results show that this method is effective for continental aerosol mixtures consisting of dust and pollutants. It is also seen that the dust loading mainly occurred in the free troposphere $(<6 \mathrm{~km})$, with the average mass loading of $905 \pm 635 \mu \mathrm{g}$ $\mathrm{m}^{-2}$ trapped in the planetary boundary layer. The dust MEE ranges from 0.30 to $0.60 \mathrm{~m}^{2} \mathrm{~g}^{-1}$ and has a significantly negative relationship with the size of dust particles. With the assumption of the dust MEE of $0.37(0.60) \mathrm{m}^{2} \mathrm{~g}^{-1}$, the DMC is shown to be overestimated (underestimated) by $20-40 \%$ (15-30\%). In other words, our results suggest that the change of MEE with the size of dust particles should be considered in the estimation of DMC.
\end{abstract}

Keywords: dust mass concentration; mass extinction efficiency; identification and separation of dust aerosol; lidar-photometer method; Northwest China

\section{Introduction}

Mineral dust aerosols, as one of the major components of tropospheric atmospheric aerosols, significantly affect the radiation energy budget and contribute to climate change through direct, semi-direct, and indirect effects [1-8], the global biogeochemical cycle [9-12], and human and ecosystem health $[13,14]$. To understand these impacts, accurate assessments of dust emission, transport, deposition, and the whole cyclic process are required $[15,16]$.

Model simulation is an effective tool for quantification of the emission, transport, and deposition of dust aerosols on regional and global scales [17,18]. Global and regional climate models have been also widely applied to evaluate the effect of dust on the climate and environment $[19,20]$. Nevertheless, a rather high level of uncertainty is attributed to the model simulation [21]. Hence, it is an immediate need to evaluate and constrain a model simulation using reliable observations and assess the abovementioned climatic and environmental effects of dust aerosols with a higher level of certainty. Although satellite remote sensing is often considered a powerful tool to study the aerosol optical properties, e.g. [22-25], and assess the cyclic process of dust aerosol, e.g. [22,26-29], it has several important drawbacks. 
Due to their large spatial and temporal coverage, satellite-based passive observations have been used to characterize specific dust cyclic processes. For instance, Kaufman et al. [22] estimated the trans-Atlantic dust transport and deposition flux using the Moderate Resolution Imaging Spectroradiometer (MODIS) observation. Furthermore, using the MODIS Deep Blue aerosol products Ginoux et al. [27] attributed dust sources to natural and anthropogenic origins and evaluated their contributions and emission rates on a global scale. Estimating the dust flux based on passive remote sensing is however subject to considerable uncertainties associated with the accuracy of dust identification, the derived dust optical depth (DOD), the simplified dust vertical distribution, and the assumed dust mass extinction efficiency (MEE) that converts DOD to dust mass concentration (DMC).

Active lidar remote sensing is an effective alternative method to identify dust aerosols. Lidar remote sensing utilizes advanced depolarized technology to obtain the dust extinction coefficient profile. The Cloud-Aerosol Lidar with Orthogonal Polarization (CALIOP) and other satellite-based radiometers were recently used to assess the transport and deposition flux of dust aerosols from North Africa along with the trans-Atlantic transit [26,29]. Huang et al. [28] also used the CALIOP to detect the global distribution of anthropogenic and natural dust sources and to further evaluate the respective dust column burden. Nevertheless, due to the assumptions on dust lidar ratio and the misidentification of the dust layer base, the DOD obtained from CALIOP is underestimated by $26 \%$ [30]. Furthermore, the assumed dust MEE significantly differs across the existing research works, e.g., a fixed constant of $0.37 \mathrm{~m}^{2} \mathrm{~g}^{-1}$ is considered in [22,26] and $0.6 \mathrm{~m}^{2} \mathrm{~g}^{-1}$ in [28]; also a linearly-varying value model along the transport route is adopted in [29]. The uncertainties introduced by the assuming MEE and the corresponding retrieval of DOD result in inaccurate quantification of DMC or dust flux.

Dust MEE is a key converting factor that transforms the DOD (or the corresponding dust extinction coefficient (DEC) profile) into the columnar DMC (or the corresponding DMC profile). Due to the limitation of the existing satellite remote sensing technology, it is extremely challenging to directly derive the MEE. To address this issue, it is often assumed as a fixed constant or a linearly varying function. To obtain accurate dust MEE, airborne or ground-based observations can be also employed. For example, based on the in situ airborne observation, Osborne et al. [31] and Johnson and Osborne [32] derived the dust MEE of 0.30 0.40, and $0.48 \pm 0.10 \mathrm{~m}^{2} \mathrm{~g}^{-1}$, respectively for West Africa. Based on the multi-wavelength lidar, Weinzierl et al. [33] and Müller et al. [34] also obtained dust MEE values of $0.45 \sim 0.70$, and $0.57 \pm 0.04 \mathrm{~m}^{2} \mathrm{~g}^{-1}$ respectively for a Saharan dust layer above $2 \mathrm{~km}$ over south Morocco. The sun-photometer has been also shown to have the potential to estimate the dust MEE using the column-integrated particle volume concentration, DOD, and an assumed dust density [35]. The large range of dust MEE at different studies is mainly attributed to the changes in the distribution of dust particle size. Maring et al. [36] further confirmed that the dust transport from the African coast to the Caribbean results in a 15\% increase of dust MEE. These results suggest that the assumption made for dust MEE is an important source of uncertainty in the satellite-based DMC estimation.

In practice, ground-based polarization lidar and sun-photometer were combined to improve the accuracy of DMC estimation. The polarization technology of lidar facilitates the identification and separation of dust and anthropogenic pollution. Several sun-photometer observations are also used to derive the dust MEE. Ansmann et al. [37] presented a combined lidar-photometer approach to separate the optical effects caused by weakly light depolarizing fine-mode particles and strongly light depolarizing ash particles. Wagner et al. [38] evaluated the performance of lidar-photometer settings for determining the optical and microphysical properties of irregularly shaped dust particles. Moreover, Nemuc et al. [39] confirmed the reliability of the lidar-photometer method for estimating the DMC of Saharan dust by comparing the retrieval from multi-wavelength depolarization Raman lidar, and the forecasts provided by the Dust Regional Atmospheric Model. Mamouri and Ansmann [35] further extended the above method to separate the fine- and coarse-modes dust properties. Mamouri and Ansmann [40] further showed the potential of 
this method to separate fine dust, coarse dust, maritime, and anthropogenic aerosol profiles, and further derived their corresponding DMC. The above research works confirm that the lidar-photometer method can accurately retrieve the vertical profiles of the particles, their optical and microphysical properties, and their DMC.

East Asia is the second-largest dust source after Africa. Several intensive field experiments, e.g., ACE-Asia [41], ADEC [42], PACDEX [43], and EAST-AIRC [44], as well as ground-based aerosol monitoring networks, e.g., AERONET [45,46], SKYNET [47,48], and CARSNET [49,50], probed the Asian mineral dust. Such studies are essential for a thorough understanding of the climatic impacts of Asian dust. Nevertheless, dust aerosol, emitted from the desert sources (e.g., Taklamakan Desert, Kumtag Desert, Badain Jaran Desert, Tenger Desert, and Qaidam Desert, refer to the map in Figure 1) and by agricultural cultivations (e.g., land planning, plowing, and disking) in Northwest China, commonly mix with anthropogenic pollutants while traveling eastward [51]. The coexistence of dust and other types of aerosols is ubiquitous and further increases the complexity and variability of aerosols' key parameters [52,53]. Although several studies focused on the optical and microphysical properties of dust aerosols [51,54-58], only a few studies estimated the MEE and DMC for the East Asian dust based on the ground or satellite remote sensing. The only exception is the element tracer method based on chemical analyses presented in $[59,60]$.

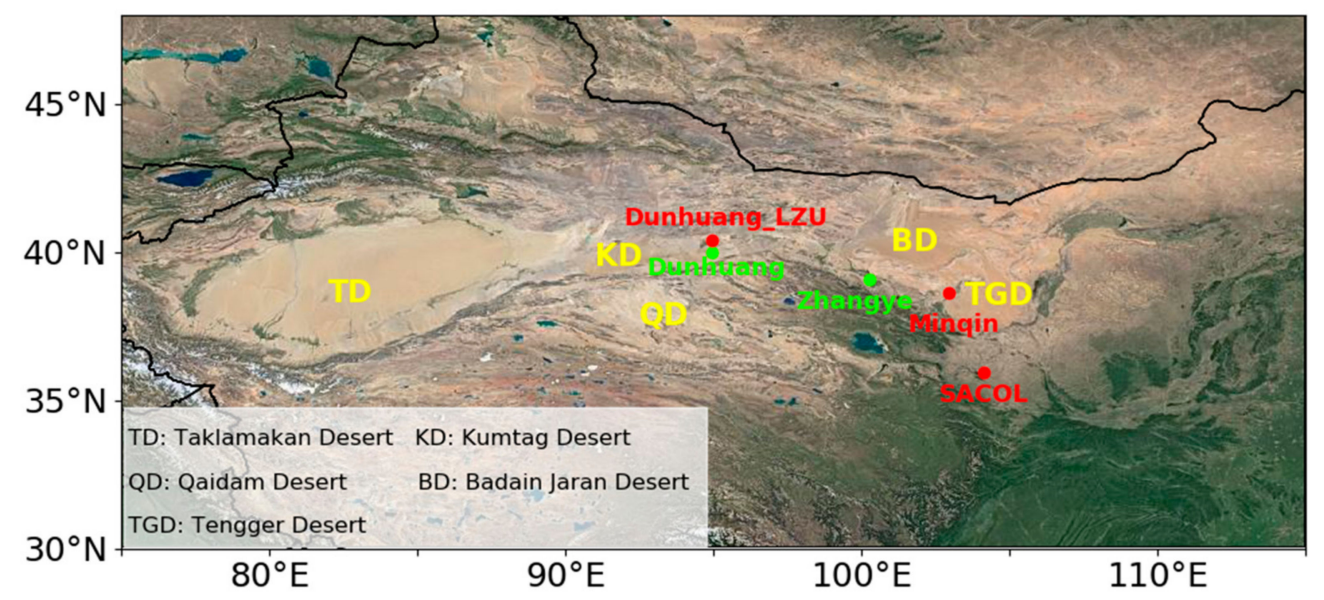

Figure 1. The geographical distribution of dust sources and the field observational sites in Northwest China. The sunphotometer (all sites) and lidar (only red sites) are utilized in this study.

In this research work, we address the following research questions: How different is the MEE of Asian dust from that of in Africa? How is the uncertainty in the DMC estimation affected by the MEE assumption? In this study, the lidar-photometer method is applied to four intensive dust field experiments and one long-term observation in Northwest China. The objectives are to separate the mineral dust and anthropogenic pollution, deriving the dust MEE, and vertically resolved DMC in Northwest China. We then assess the uncertainties of DMC caused by assuming the value of dust MEE and the retrieval error of DOD. The objectives of this research are to: (1) improve the understanding of the dust MEE and vertical-resolved DMC in Northwest China, and (2) provide an insight into the uncertainties of satellite-based DMC upon assuming the value of dust MEE.

In the following, the dust field experiments, and measurements, and the specific retrieval methods are briefly introduced in Sections 2 and 3, respectively. The primary results are analyzed in Section 4. The uncertainties in estimating DMC are discussed in Section 5. Finally, the concluding remarks are presented in Section 6.

\section{Field Experiments and Measurements}

The measurements data we use in this study are based on four intensive dust field experiments at sites located in Northwest China (including Dunhuang, Zhangye, Min- 
qin, Dunhuang_LZU), and a permanent site of the Semi-Arid Climate and Environment Observatory of Lanzhou University (SACOL), see Figure 1.

The comprehensive dust experiments at Dunhuang were conducted by the ACE-Asia field campaign in the spring of 2001. The SACOL Ancillary Facility also conducted the dust field experiments at Dunhuang_LZU in the spring of 2012. These two sites are close to the eastern edge of the Kumtag Desert and about $450 \mathrm{~km}$ in the downwind zone of the Taklamakan Desert. During the time between April to June of 2008, the U.S. Department of Energy Atmospheric Radiation Measurement (DOE/ARM) Ancillary Facility was established at Zhangye. Zhangye is located on the southern edge of the Badain Jaran Desert and in the semi-arid area of Northwest China.

The SACOL Ancillary Facility also conducted another field campaign at Minqin, which is adjacent to the southeast margin of Badain Jaran Desert and the western border of the Taklamakan Desert about $300 \mathrm{~km}$ away to the southeast Zhangye. The dust aerosols over these sites are commonly mixed with anthropogenic pollutants, e.g., coal combustion, mobile source emissions, and biomass burning [51]. The SACOL is located far from the desert sources hence represents the transport area of dust in Northwest China. Besides the extensive examination of aerosols' chemical and physical properties, these experiments include radiation and remote sensing measurements to investigate the optical properties and radiative impacts of Asian dust. The details of the conducted experiments are presented in Table 1.

These experiments provide us with an opportunity to understand the MEE of the Asian dust and its impact on the DMC in dust and polluted dust conditions. To address the requirements of the lidar-photometer method, in this study we utilize the observations of Micro Pulse Lidar (MPL) and sun-photometer (CE318) from Aerosol Robotic NETwork (AERONET) deployed on these sites.

Table 1. The detailed information of the utilized dust field experiments.

\begin{tabular}{lllll}
\hline \multicolumn{1}{c}{ Sites } & \multicolumn{1}{c}{ Lat/Lon } & Elevation & \multicolumn{1}{c}{ Periods } & \multicolumn{1}{c}{ References } \\
\hline Dunhuang & $40.04^{\circ} \mathrm{N}, 94.79^{\circ} \mathrm{E}$ & $1381 \mathrm{~m}$ & March-May, 2001 & Huebert et al. [41] \\
Zhangye & $39.08^{\circ} \mathrm{N}, 100.28^{\circ} \mathrm{E}$ & $1461 \mathrm{~m}$ & April-June, 2008 & Huang et al. [55] \\
Minqin & $38.61^{\circ} \mathrm{N}, 102.96^{\circ} \mathrm{E}$ & $1373 \mathrm{~m}$ & April-June, 2010 & Bi et al. [56] \\
Dunhuang_LZU & $40.49^{\circ} \mathrm{N}, 94.96^{\circ} \mathrm{E}$ & $1061 \mathrm{~m}$ & April-June, 2012 & Bi et al. [51] \\
SACOL & $35.57^{\circ} \mathrm{N}, 104.08^{\circ} \mathrm{E}$ & $1966 \mathrm{~m}$ & August 2007-May 2013 & Huang et al. [61] \\
\hline
\end{tabular}

The MPL is a compact and maintenance-free standard lidar system running within the MPLNET. It is used for acquiring continuous profiles of the attenuated backscatter coefficient and the depolarization ratio of aerosols and clouds. This system consists of a low-energy pulse of 7 8 $\mu \mathrm{J} \mathrm{Nd:YLF} \mathrm{pulsed} \mathrm{laser} \mathrm{at} 527 \mathrm{~nm}$ with a relatively high repetition frequency of $2500 \mathrm{~Hz}$. The diameter of the telescope-receiver system is also $20 \mathrm{~cm}$. In September 2009, the lidar system was upgraded with a polarization detector and continual aerosol and cloud measurements are acquired with $30 \mathrm{~m}$ range resolution and $1 \mathrm{~min}$ integrating time. Accurate profiles of the attenuated backscattering coefficient and depolarization ratio are acquired using a series of corrections (e.g., dead time, background signal, afterpulse, overlap, and range-corrected) according to the standard methods as in Campbell et al. [62]. We use the three MPLs (including Minqin, Dunhuang_LZU, and SACOL) to characterize the vertical structures of DMC in Northwest China. The inversion products including the backscatter coefficient, backscatter ratio, cloud height, cloud thermodynamic phase, and aerosol layer height are also obtained using an automatic detection algorithm [63].

The AERONET sun-photometer is an automatic direct solar and sky radiometer. Its spectral range is $340 \sim 1020 \mathrm{~nm}$ [45] and it can obtain various spectral atmospheric aerosol optical properties with high accuracy. From the spectral AOD distribution, the Ångström Exponent (AE), volume size distribution, and fine- and coarse-modes' AOD [64,65] are also obtained. The AOD retrieval error is less than $\pm 0.01 \%$, and the retrieval error of particle 
volume concentrations is about $10-20 \%$ [66]. Undefined uncertainties may occur in the retrieval of the volume size distribution close to the desert-sources, where a considerable number of dust particles with radii greater than $15 \mu \mathrm{m}$ may exist that can affect the measured optical properties [67]. Here we use, the cloud-screened and quality-assured Version 3 level 2.0 aerosol products from AERONET sun-photometer at all five sites to derive the dust MEE. The column AODs are then converted at a wavelength of $527 \mathrm{~nm}$ following the Ångström formula to match the MPL-based observations.

\section{Retrieval Methods}

\subsection{Retrieval of Dust MEE from AERONET Sun-Photometer}

An important prerequisite of the lidar-photometer method for the DMC is the existence of converting factor, dust MEE, between the lidar-derived particle extinction coefficient and particle mass concentration. The similar converting factor, the ratio of extinction to volume concentration, is also intensively studied based on long-term AERONET sun-photometer observations in Africa and Europe during field campaigns [37]. Dust aerosols are mainly composed of a large number of coarse-mode dust particles ( $>1 \mu \mathrm{m}$ diameter) and fine-mode clays with about 10\% dust mass [68]. Dust aerosols in Northwest China are mainly emitted from arid and semi-arid regions and areas with strong agricultural activities. Therefore, the coarse-mode particles derived from AERONET sun-photometer are mainly controlled by the dust aerosol and unaffected by sea salt. The fine-mode particles are usually the mixture of fine-mode dust and anthropogenic pollution. Similar to Ansmann et al. [37], the dust MEE $\left(k_{d}\right)$ in this study can be defined by using the coarse-mode properties to reduce the effect of fine-mode pollution:

$$
k_{d}=\frac{1}{n} \sum_{i=1}^{n} k_{d, i}=\frac{1}{n} \sum_{i=1}^{n} \frac{\tau_{c, i}}{\rho_{d} v_{c}}
$$

where $\tau_{c}$ and $v_{c}$ are the coarse-mode AOD (CAOD), and volume concentration (CVC) obtained from the AERONET sun-photometer, respectively. Furthermore, in (1) $\rho_{d}$ denotes the dust particle density which is assumed to be $2.6 \mathrm{~g} \mathrm{~cm}^{-3}[69,70]$. The two different sets of $\tau_{c, i}$, obtained from the Spectral Deconvolution Algorithm (SDA) [64] and the AOD related to the segments of volume size distribution [65], are used to compute the $k_{d, i}$, respectively, and then averaged to represent the best dust MEE. To increase the reliable retrieval of $\tau_{c}$ and $v_{\mathcal{C}}$ we only select cases with a coarse-mode fraction (CMF, the ratio of CAOD and total AOD) larger than $20 \%$. This is due to the small impact of the coarse-mode particles on the measured optical properties. For the detailed discussion, see Section 3.2 in Ansmann et al. [37]. Note that unlike Ansmann et al. [37], to explore the relationship between the dust MEE and its properties, the dust MEE is calculated for all individual dust observations and not averaged over long time series in this study.

\subsection{Retrieval of DMC Profiles from MPL}

The lidar-photometer method exploits the separation of non-spherical dust and spherical pollution to obtain the dust optical properties and mass concentration. This method was extended by Mamouri and Ansmann [35] to further separate coarse-mode and fine-mode dust particles. Nevertheless, because of the larger number of input parameters, the level of uncertainties may be larger than that of the original method. In this study, we adopt the original lidar-photometer method to separate and retrieve the optical properties and mass concentration of dust particles from the total aerosols.

The MPL-based lidar-photometer method has been firstly used to separate the aerosol mixtures and derive their optical properties by [71]. The specific algorithm adopted in this study is described in the following. For brevity, the dependence on height is not indicated. The normalized relative backscatter (NRB) from MPL measurements is processed by using the automated detection and classification algorithm of the atmospheric particle layer developed by Xie et al. [63]. This algorithm avoids the misclassification of the dense dust aerosol layer as ice clouds for one elastic channel lidar, e.g., MPL, without the best 
estimation of the lidar ratio (LR). The volume linear depolarization ratio (VDR) is then obtained and calibrated from the MPL depolarization ratio (the ratio of signals from the "cross-polar" and "co-polar" channels) [72]. In the next step, the overall aerosol particulate linear depolarization ratio (PDR), $\delta_{a}$ is converted from the VDR. To do this, we use the determined molecular depolarization ratio (which is assumed to be 0.00363 ) and the calculated aerosol scattering ratio. In this study, the overall aerosol backscatter coefficient $(\mathrm{ABC})$ is retrieved from the solution of the Fernald inversion with an assumed lidar ratio of $50 \mathrm{sr}$. For calibrating the profile of the elastic backscatter signal, we simulate Rayleigh scattering signals based on actual temperature and pressure profiles from the ERA-Interim data [73]. More details are available in Xie et al. [63] and Zhou et al. [74].

The backscatter coefficient (BC) of dust particles, $\beta_{d}$ is then obtained from the overall $\mathrm{ABC}, \beta_{a}$, according to the determined PDR of dust, $\delta_{d}$, and non-dust, $\delta_{n d}$, as the following [75]:

$$
\beta_{d}=\beta_{a} \times \frac{\left(\delta_{a}-\delta_{n d}\right)\left(\delta_{d}+1\right)}{\left(\delta_{a}+1\right)\left(\delta_{d}-\delta_{n d}\right)}
$$

The accuracy of $\beta_{d}$ depend on $\delta_{d}$ and $\delta_{n d}$. The value of $\delta_{d}$ is often in the range of $0.30 \sim 0.35$ for Saharan dust source $[76,77]$ or Taklamakan dust source and after long-range transport towards Europe [78] or Japan [79,80]. The values of $\delta_{d}$ and $\delta_{n d}$ in this study are set to 0.31 , and 0.05 , respectively, to avoid unnecessary exclusion or inclusions of dust events according to Mamouri and Ansmann [35]. The values of $\beta_{d}$ or $\beta_{n d}$ are assigned to $\beta_{a}$ when $\delta_{a}>\delta_{d}$ for dust bins or $\delta_{a}<\delta_{n d}$ for non-dust bins, respectively. Afterward, similar to Ansmann et al. [37], profiles of DMC, $m_{d}$ for total dust particles are derived from the calculated $\beta_{d}, k_{d}$, and a determined dust lidar ratio, $S_{d}$, as:

$$
m_{d}=\frac{\beta_{d} S_{d}}{k_{d}}
$$

where the $S_{d}$ is set to 44 referring the observations from ground-based Raman lidar observations $[81,82]$ and satellite-based lidar $[30,83]$. Note that here the contributions of small non-spherical particles to the fine-mode backscatter coefficient are ignored and the large spherical particles are interpreted as fine-mode backscatter in this approach $[84,85]$.

\section{Results}

\subsection{Identification and Classification of Dust Aerosol}

The depolarization ratio observed by polarization lidar is often adopted for the accurate identification and classification of the dust aerosols. The PDR of the mineral dust particle is observed in the range of $0.3 \sim 0.35$ over the dust sources and long-range transport. However, it is seen that the PDR is decreased. This is most likely caused by the mixing and contamination (coating) of desert dust particles with other weak-depolarizing or hygroscopic particles.

Dust and polluted dust are classified and analyzed in previous studies [81,83,86,87]. Usually, the aerosol particles with the PDR greater than 0.31 are classified as pure mineral dust, whereas others are classified as polluted dust. For passive remote sensing, the aerosol particles are also classified according to their optical parameters, e.g., AE, which are observed by surface-based sun-photometers [88] or satellite-based spectrometers [27]. Therefore, for the lidar-photometer method, here, we confirm the consistency of identification and classification of dust and polluted dust based on the lidar and sunphotometer observations.

Figure 2a presents the relationship between the $\mathrm{AE}$ at 440 and $870 \mathrm{~nm}$ wavelength (AE $440-870), C A O D$ at $500 \mathrm{~nm}, \mathrm{CMF}$ from sun-photometer, and the column-mean PDR from lidar during the collocated observations at Dunhuang_LZU, Minqin, and SACOL sites. The $\mathrm{AE}_{440-870}$ and $\mathrm{CMF}$ represent the relative size of aerosol particles, and the proportion of coarse particles, respectively. As it is seen, $\mathrm{AE}_{440-870}, \mathrm{CMF}$, and CAOD are significantly correlated with the column-mean PDR. By increasing PDR, the CMF and CAOD are increased from 0.4 to 0.9 , and from 0.05 to 1.1 , respectively, but $\mathrm{AE}_{440-870}$ is 
decreased from 1.2 to 0 . The $\mathrm{AE}_{440-870}$ and $\mathrm{CMF}$ intersect at 0.2 and 0.8 with the PDR turning point of 0.31 between the dust and polluted dust, respectively. This suggests that the pure mineral dust aerosols dominated by coarse-mode large particles can be strictly classified by $\mathrm{AE}_{440-870} \leq 0.2$ and $\mathrm{CMF} \geq 0.8$, which are consistent with the classification of pure mineral dust aerosol in Bi et al. [88] and Burgos et al. [86]. For the polluted dust, the mixing degree of weak-depolarizing fine particles and strong-depolarizing dust particles in the atmosphere can also be indirectly obtained using the sun-photometer observations for $0.2<\mathrm{AE}_{440-870} \leq 1.2$.
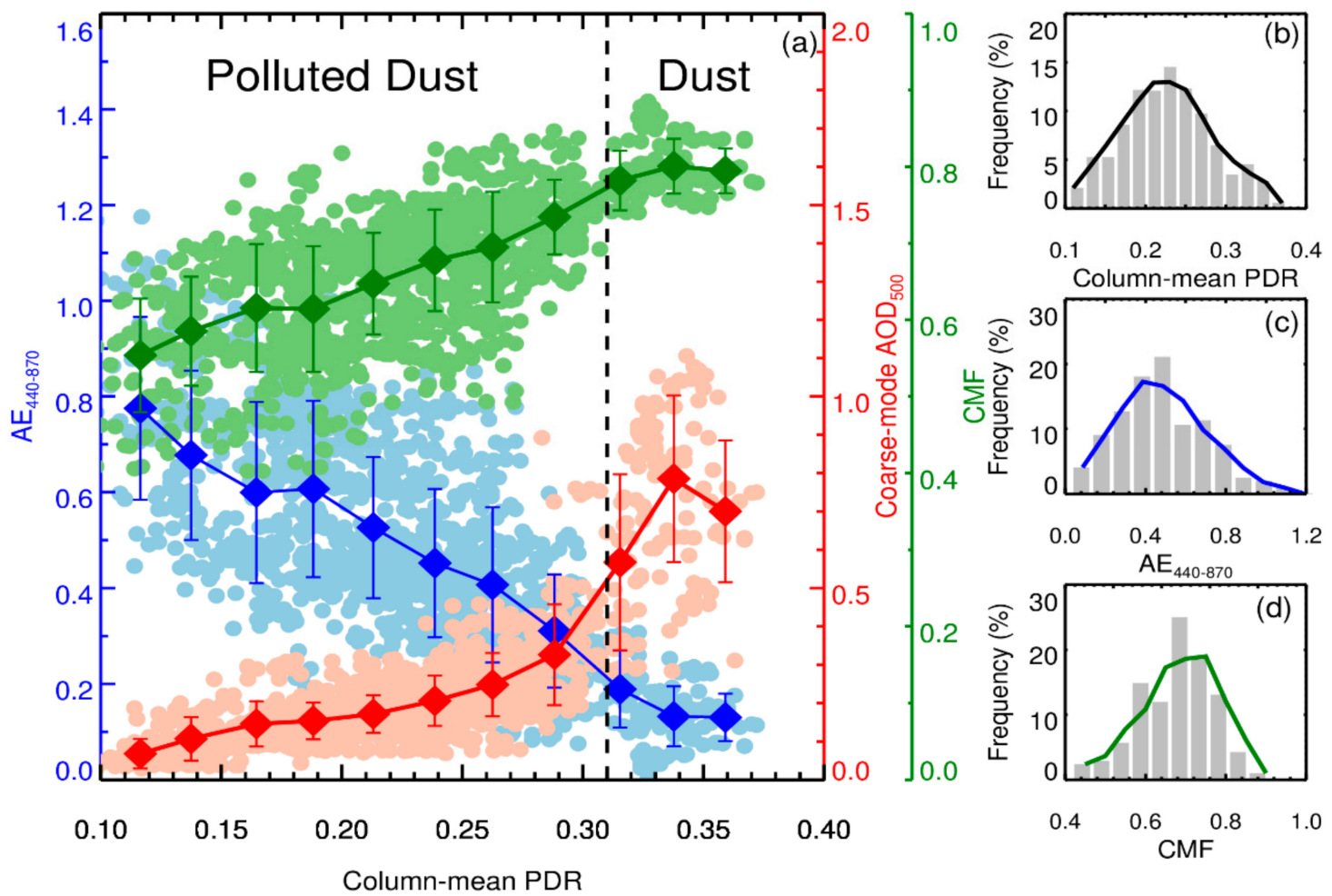

Figure 2. (a) The relationship between $\mathrm{AE}_{440-870}$ (blue), coarse-mode $\mathrm{AOD}_{500}$ (red), coarse-mode fraction (CMF; green) and column-mean PDR in the Northwest China. The diamonds and whiskers represent the average and SD of AE $440-870$, coarse-mode $\mathrm{AOD}_{500}$, and $\mathrm{CMF}$ in each PDR bin. The vertical dashed lines denote the turning point between the dust and polluted dust according to the PDR threshold of Asian dust (0.31). The frequency distribution of (b) PDR, (c) AE $440-870$, and (d) CMF are also in the right panel, respectively (total samples: 1260).

Figure $2 b-d$ present the frequencies of the column-mean PDR, AE $440-870$, and CMF at Dunhuang_LZU, Minqin, and SACOL sites in Northwest China, respectively. The columnmean PDR is mainly in the range of 0.10 to 0.36 with a peak of 0.24 , and over $90 \%$ of PDRs are less than 0.31. Similarly, $87 \%$ of $\mathrm{AE}_{440-870}$ exhibit the polluted dust features (i.e., $\mathrm{AE}_{440-870}>0.2$ ). This suggests that the polluted dust dominates the pure dust. This is due to the $86 \%$ contribution of the observation samples from the SACOL site (see Table 2) and represents the typical characteristics of transported dust mixed with anthropogenic pollution. The CMF range is from 0.4 to 0.9 with a peak of 0.7 , which suggests that the majority of aerosols in Northwest China are coarse-mode particles.

Therefore, to deeply understand the difference between the optical properties of dust and DMC for various mixtures of anthropogenic pollution and dust particles, here, we classify dust aerosols of Northwest China into three sub-types including $\mathrm{AE}_{440-870} \leq 0.2$ (DD), $0.2<\mathrm{AE}_{440-870} \leq 0.6$ (PD-I), and $0.6<\mathrm{AE}_{440-870} \leq 1.2$ (PD-II) with CMF $>0.4$. 
Table 2. The average and SD of four key parameters at five sites in Northwest China for the DD, PD-I, and PD-II conditions.

\begin{tabular}{ccccccc}
\hline Sites & Types & CAOD & CMF & CVC & CER $(\mu \mathrm{m})$ & Samples \\
\hline \multirow{2}{*}{ Dunhuang } & DD & $0.33 \pm 0.18$ & $0.82 \pm 0.02$ & $0.28 \pm 0.15$ & $1.74 \pm 0.10$ & 8 \\
& PD-I & $0.21 \pm 0.03$ & $0.78 \pm 0.01$ & $0.18 \pm 0.03$ & $1.84 \pm 0.10$ & 7 \\
\hline \multirow{3}{*}{ Zhangye } & DD & $0.52 \pm 0.15$ & $0.79 \pm 0.03$ & $0.54 \pm 0.15$ & $2.17 \pm 0.23$ & 14 \\
& PD-I & $0.21 \pm 0.06$ & $0.67 \pm 0.05$ & $0.18 \pm 0.03$ & $1.93 \pm 0.25$ & 44 \\
& PD-II & $0.16 \pm 0.04$ & $0.46 \pm 0.06$ & $0.13 \pm 0.04$ & $1.88 \pm 0.12$ & 12 \\
\hline \multirow{2}{*}{ Minqin } & DD & $0.31 \pm 0.04$ & $0.80 \pm 0.02$ & $0.25 \pm 0.03$ & $1.73 \pm 0.03$ & 4 \\
& PD-I & $0.18 \pm 0.04$ & $0.70 \pm 0.06$ & $0.15 \pm 0.04$ & $1.82 \pm 0.13$ & 13 \\
\hline \multirow{5}{*}{ Dunhuang_LZU } & DD & $0.79 \pm 0.23$ & $0.80 \pm 0.02$ & $0.66 \pm 0.21$ & $1.76 \pm 0.17$ & 19 \\
& PD-I & $0.25 \pm 0.09$ & $0.72 \pm 0.03$ & $0.20 \pm 0.09$ & $1.73 \pm 0.18$ & 24 \\
& PD-II & $0.15 \pm 0.00$ & $0.54 \pm 0.00$ & $0.12 \pm 0.00$ & $1.83 \pm 0.00$ & 1 \\
\hline \multirow{2}{*}{ SACOL } & DD & $0.72 \pm 0.29$ & $0.81 \pm 0.03$ & $0.64 \pm 0.26$ & $1.83 \pm 0.15$ & 40 \\
& PD-I & $0.26 \pm 0.09$ & $0.66 \pm 0.05$ & $0.23 \pm 0.09$ & $1.96 \pm 0.27$ & 294 \\
& PD-II & $0.12 \pm 0.05$ & $0.38 \pm 0.11$ & $0.12 \pm 0.06$ & $2.16 \pm 0.32$ & 566 \\
\hline
\end{tabular}

\subsection{Optical and Microphysical Properties of Dust Aerosols}

To investigate the difference between dust and polluted dust at the sites in Northwest China, here, we statistically compare their optical and microphysical properties associated with the lidar-photometer method under the three abovementioned classification criteria. Table 2 lists the average and standard deviation (SD) of four key parameters at the five sites throughout observations. Note that a small number of statistical samples is used in this study. This is because: (1) the inversion samples of volume size distribution are significantly less than that of the SDA algorithm, and (2) there is no retrieval of coarsemode aerosol optical properties due to the lack of observations at $500 \mathrm{~nm}$ wavelength from September 2008 to August 2010 and from May 2011 to September 2012. Therefore, no PD-II dust aerosol event is classified during the intensive field experiment at Dunhuang and Minqin sites.

The permanent site of SACOL only contributes 900 samples. However, these samples are sufficient to indicate the differences between DD, PD-I, and PD-II dust aerosols. It is also seen that the CAOD, CMF, and CVC at all sites are gradually decreased during the transition from pure dust to polluted dust with the increase of anthropogenic pollution. The CMF is always greater than 0.79 at all sites under the DD conditions, either near the desert or in the transport area. This ensures the accuracy of pure dust identification at the sites without lidar. However, there are significant differences in the CVC, CAOD, and coarse-mode effective radius (CER) across all sites. This is most likely related to the strength of the dust weather process during the period of observations. These differences also result in different dust MEE as discussed in Section 4.3.

Figure 3 shows the average volume size distribution for five sites for the DD, PD-I, and PD-II conditions. During the transition from dust to polluted dust, it is seen that the average volume size distribution gradually changes from single-peak to double-peak with significantly decreasing CVC (from 0.6 to 0.07 ) and CMF (0.80 to 0.39 ). However, the average value of CER is increased from $1.86 \pm 0.21,1.94 \pm 0.26$, to $2.15 \pm 0.32 \mu \mathrm{m}$. This might be closely related to the relatively large sample contribution of the SACOL site with a larger CER of $1.96 \pm 0.27$ and $2.16 \pm 0.32$ in the PD-I and PD-II conditions. The larger the SD of CER, the more significant the difference in the optical and microphysical properties in different dust weather processes. 

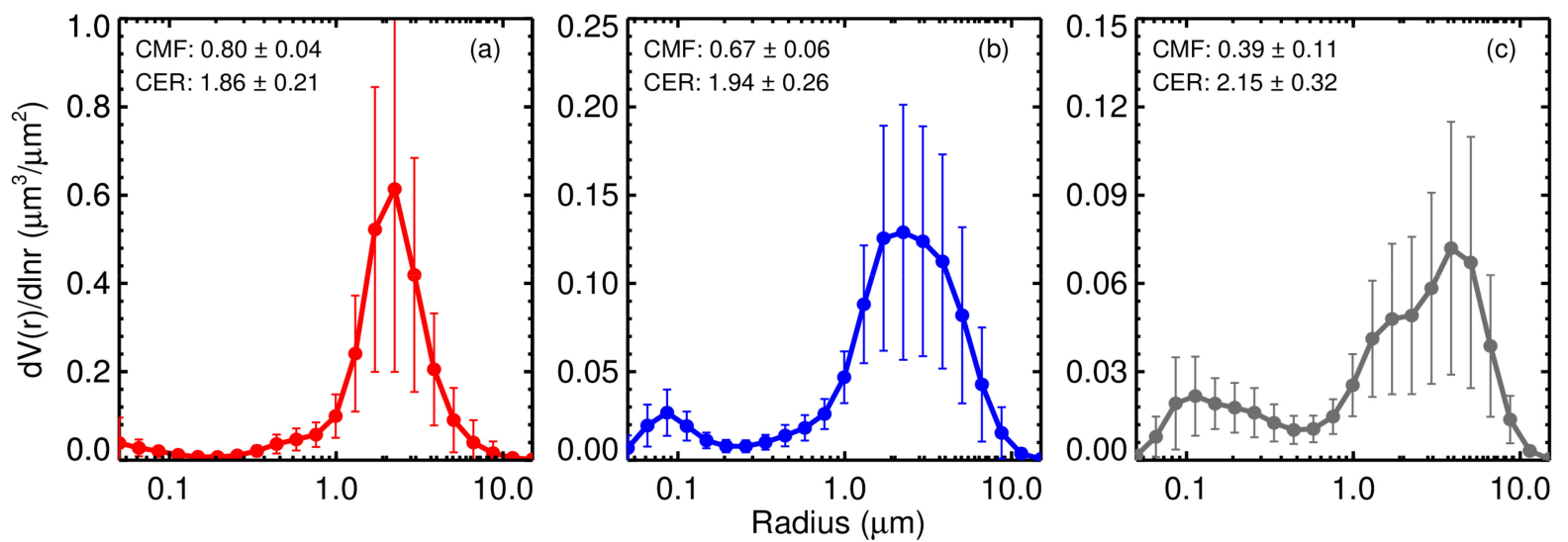

Figure 3. The average volume size distributions in Northwest China for (a) DD, (b) PD-I, and (c) PD-II conditions.

\subsection{Dust MEE in Northwest China}

According to the retrieval method of dust MEE described in Section 3.1, we obtain the dust MEE at five sites in Northwest China for the DD, PD-I, and PD-II conditions.

The frequency distributions of the dust MEE in Northwest China are shown in Figure 4a. As it is seen, their distribution follows a nearly normal distribution with the average and $\mathrm{SD}$ of $0.44 \pm 0.05,0.44 \pm 0.07$, and $0.41 \pm 0.08 \mathrm{~m}^{2} \mathrm{~g}^{-1}$, respectively.
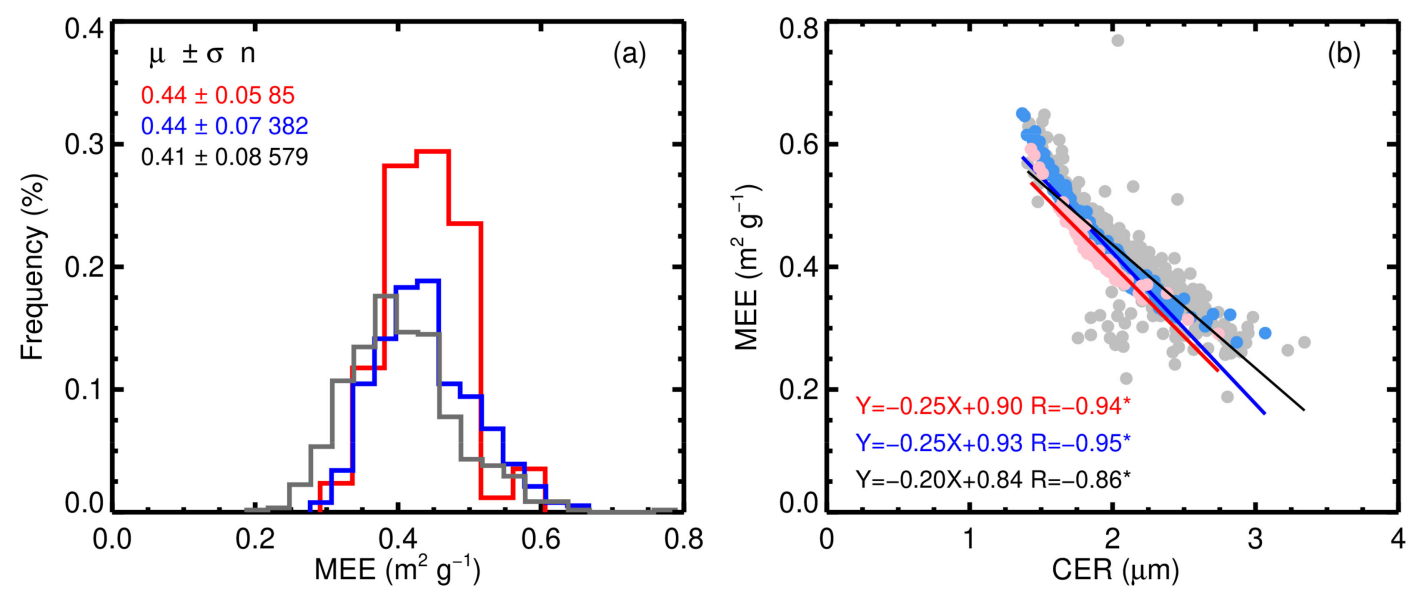

Figure 4. (a) Frequency distribution of the dust mass extinction efficiency (MEE) and (b) relationship between the dust MEE and CER for the DD (red), PD-I (blue), and PD-II (gray) conditions. The average $(\mu)$, SD $(\sigma)$, and sample size $(n)$ of the dust MEE for different conditions are labeled in the left panel. The fitting function and correlation coefficients $(R)$ at different conditions are labeled in the right panel (* represents the significant level of 0.01).

Although the dust MEE shows striking similarities among three types of dust conditions, the variances of the dust MEE is significantly increased by the transition from dust to polluted dust. The dust MEE derived from the coarse-mode optical properties is mainly in the range of $0.30 \sim 0.60 \mathrm{~m}^{2} \mathrm{~g}^{-1}$, which almost covers the in-situ airborne observation of $0.30 \sim 0.40$ and $0.48 \pm 0.10 \mathrm{~m}^{2} \mathrm{~g}^{-1}$ in West Africa by Osborne et al. [31] and Johnson and Osborne [32], and multi-wavelength lidar retrieval of $0.45 \sim 0.70$ and $0.57 \pm 0.04 \mathrm{~m}^{2} \mathrm{~g}^{-1}$ for Saharan dust layer above $2 \mathrm{~km}$ over south Morocco by Weinzierl et al. [33] and Müller et al. [34], respectively. The average of dust MEE in Northwest China is also well consistent with the Asian climatological one of $0.41 \pm 0.05 \mathrm{~m}^{2} \mathrm{~g}^{-1}$ for coarse dust particles, estimated from the 9769 individual observations of pure dust $\left(\mathrm{AE}_{440-870}<0.3\right.$ and $\left.\mathrm{AOD}>0.1\right)$ at three AERONET sites of Dushanbe in Tajikistan, SACOL in China, and Dalanzadgad in Mongolia [89]. 
The large range of dust MEE might be caused by the following two reasons. The first reason is the retrieval accuracy of coarse-mode AOD and VC based on the sun-photometer. The second reason is the changes in dust aerosol microphysical properties. To further understand the contributions of these two reasons, we analyze the relationship between the dust MEE and CER in the DD, PD-I, and PD-II conditions, as shown in Figure $4 \mathrm{~b}$. As it is seen, the scatterplots of dust MEE and CER for the three conditions indicate a significant negative linear correlation. The correlation coefficient (R) for the DD, PD-I, and PD-II conditions are up to $-0.94,-0.95$, and -0.86 , respectively while all pass the significance level of 0.01 . This suggests that the big range of dust MEE is closely related to the variation of dust CER for different dust processes.

This further indicates that the dust MEE is not a fixed value and it may significantly be affected by the size of dust particles in different dust weather processes. The results here also explain the highly biased dust MEE of $1.1 \mathrm{~m}^{2} \mathrm{~g}^{-1}$ of Saharan dust over the eastern North Atlantic Ocean obtained using airborne observations by Chen et al. [90], which is due to the low inlet sampling efficiency for particles greater than $4 \mu \mathrm{m}$.

Of course, the uncertainty of the dust MEE caused by the inaccuracy of microphysical properties retrieved from sun-photometer is extended along with the increase of anthropogenic pollution. This is the reason that the largest dispersion degree is for the PD-II as shown in Figure $4 b$.

\subsection{DMC Profile in Northwest China \\ 4.4.1. Case Studies}

Here, we illustrate the MPL-based lidar-photometer method and further evaluate its performance for separating dust particles from total aerosols and retrieving the profiles of DMC in Northwest China. We consider a dust case at Dunhuang_LZU site on 24 April 2012, and a polluted dust case at the Minqin site on 22 May 2010 as shown in Figures 5 and 6, respectively.
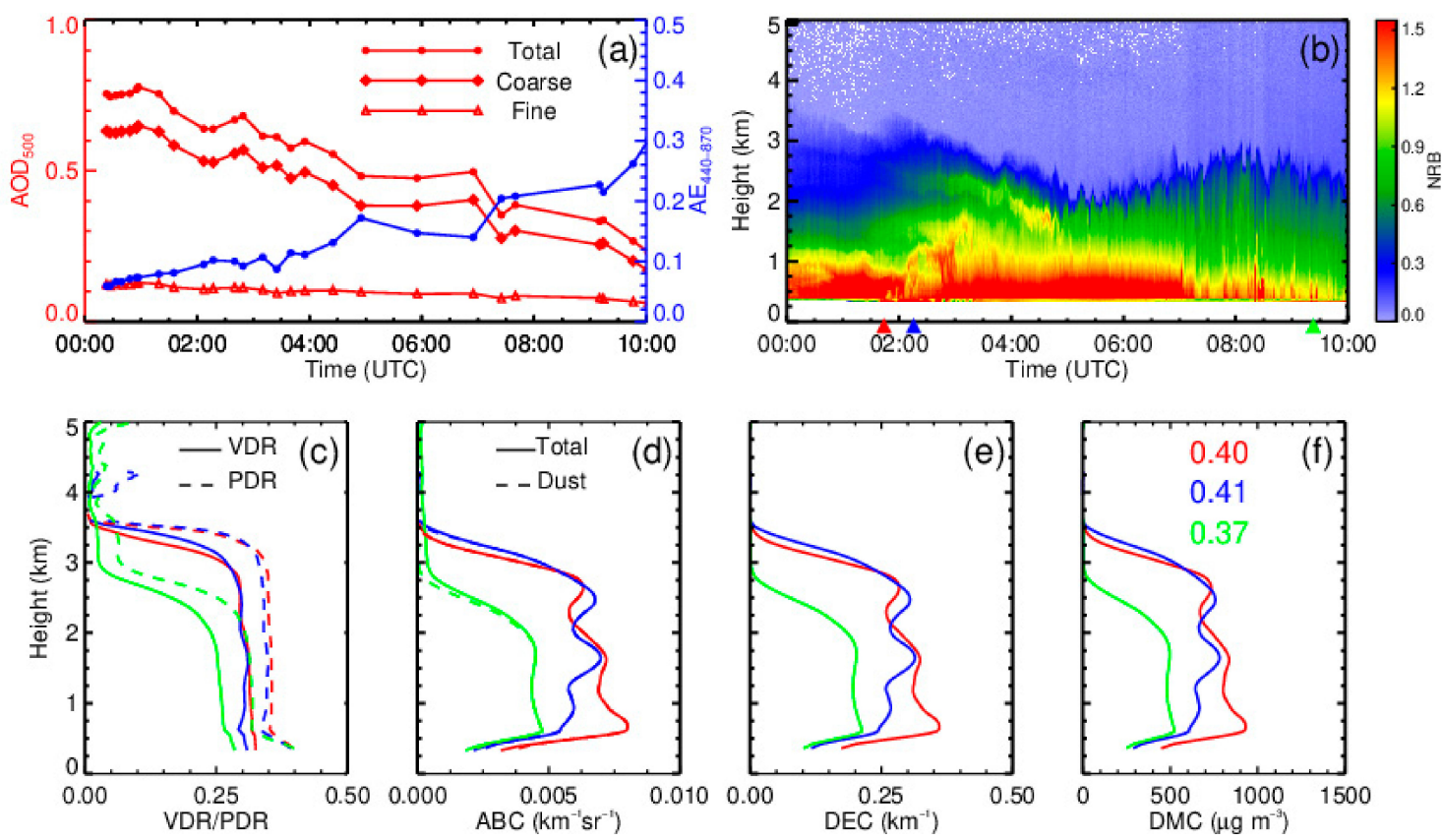

Figure 5. Time series of (a) the total, coarse-mode, and fine-mode AODs at $500 \mathrm{~nm}$ observed by the sun-photometer and (b) the NRB profile observed by the MPL at Dunhuang_LZU site on 24 April 2012. Vertical profiles of (c) VDR and PDR, (d) total and dust ABC, (e) DEC, and (f) DMC at 01:36, 02:08, and 09:15 which are labeled with the corresponding color triangles on the horizontal axis in (b). The corresponding dust MEE is also labeled in (f). 

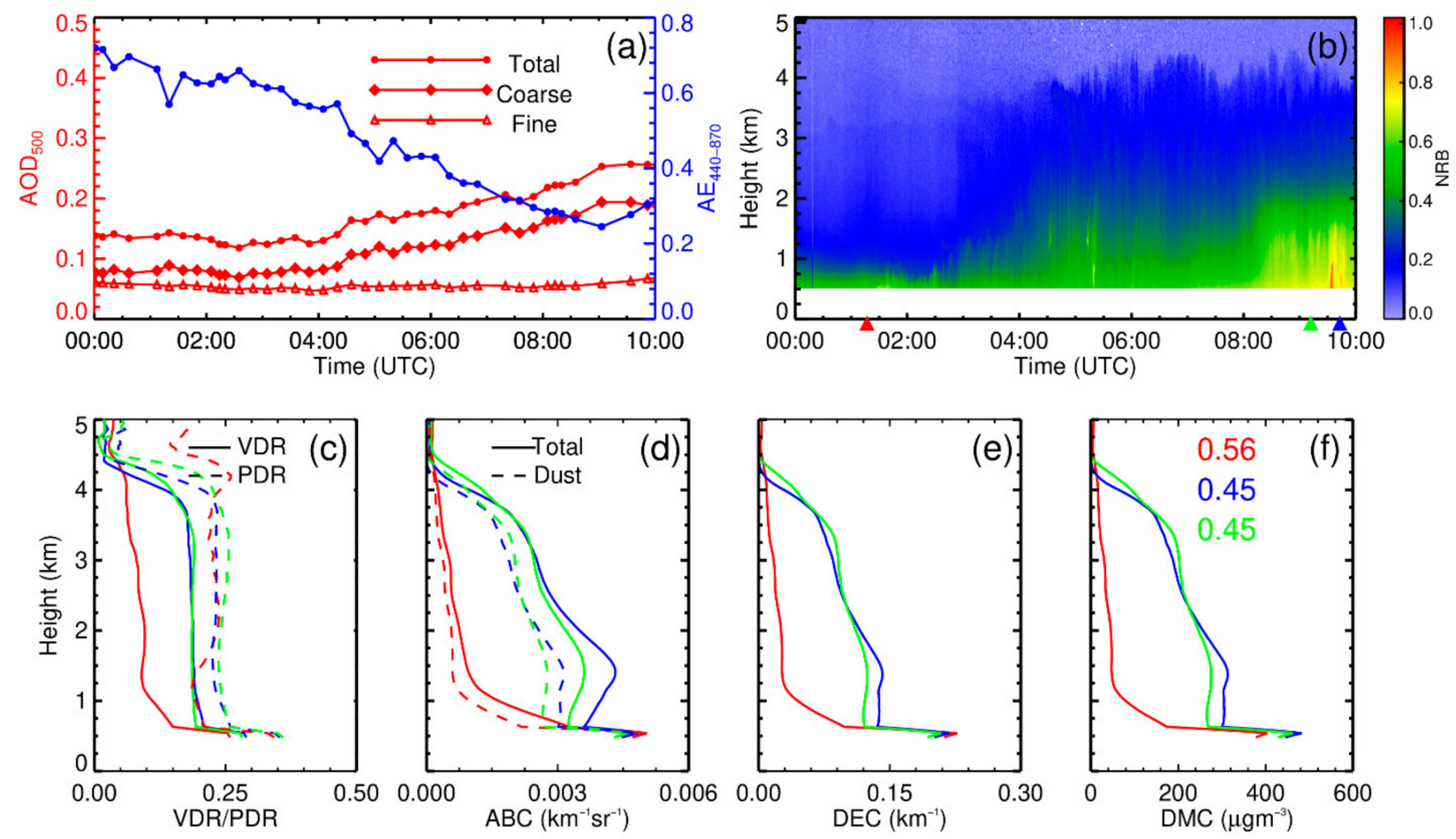

Figure 6. Same as Figure 5, but for a polluted dust case at Minqin on 22 May 2010. The color triangles on the horizontal axis in (b) correspond to 01:09, 09:04, and 09:35, respectively.

Figure 5a presents the time series of $\mathrm{AOD}$ at $500 \mathrm{~nm}$ and $\mathrm{AE}_{440 \_870}$ observed by sunphotometer on 24 April 2012. It is seen that, except for a slight decrease of fine-mode AOD, both total (coarse-mode) AODs are significantly decreased from 0.78 (0.63) at 00:30 to $0.24(0.16)$ at 10:00 by the settling of dust particles. According to the classification of dust aerosols, as indicated by the time series of AE, this can be classified as a typical DD case. Figure $5 \mathrm{~b}$ also indicates the temporal-height evolution of NRB observed by the MPL. The aerosol top layer is fluctuated with time, with the greatest height of $3.5 \mathrm{~km}$ before 03:00. The strong aerosol extinction layer is near the ground and is gradually weakened over time. Two lofted or transported dust layers can be also seen at approximately 1.5 and $2 \mathrm{~km}$ from 2:00 to 5:00. The lidar-photometer method is used to identify the aerosol types, separate the dust particles from total aerosol, and then evaluate the vertical distribution of DMC at 01:36, 02:08, and 09:15 as shown in Figure 5c-f.

The VDR and PDR profiles at the three corresponding times are shown in Figure 5c. The PDRs from the near surface to the aerosol top layer are all greater than 0.31 , except for the top border of the aerosol layer. The column-mean PDR values are $0.35,0.34$, and 0.31 at

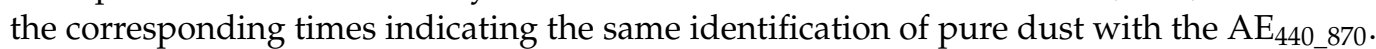
Therefore, the separated $\mathrm{BC}$ of dust particles is almost equal to the overall $\mathrm{ABC}$, as also shown in Figure 5d.

Figure $5 \mathrm{e}, \mathrm{f}$ show the DEC profiles for the pure dust LR of $44 \mathrm{sr}$ and DMC with real-time estimated dust MEE of 0.40, 0.41, and 0.37 at the corresponding times. Based on these, the fluctuation of DEC, and DMC associated with the lofted dust layers can be characterized. In general, the dust mass loading (the column-integrated DMC) is decreased from 2085, 1888 , to $977 \mu \mathrm{g} \mathrm{m}^{-2}$ with the maximum DMC of $932 \mu \mathrm{g} \mathrm{m}^{-3}$ at $0.69 \mathrm{~km}, 783 \mu \mathrm{g} \mathrm{m}^{-3}$ at $1.65 \mathrm{~km}$, and $530 \mu \mathrm{g} \mathrm{m}^{-3}$ at $0.6 \mathrm{~km}$ at the corresponding time, respectively. This confirms that the MPL-based lidar-photometer method can effectively identify the DD dust cases and obtain the profiles of DEC and DMC.

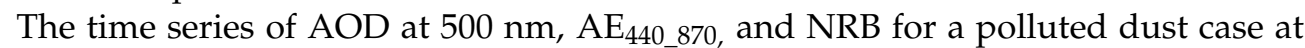
Minqin on 22 May 2010 are illustrated in Figure 6a,b. The vertical profiles of optical parameters and DMC at 01:09, 09:04, and 09:35 are also shown in Figure $6 c-f$. The changes 
in $\mathrm{AE}_{440 \_870}$ are attributed to the transition of a typical polluted dust case from PD-II to PD-I. According to the temporal-height evolution of NRB, no lofted dust plumes are observed in the air, and the strong extinction layer is only near the ground which is gradually increased and vertically transported over time. This confirms that the polluted dust case is typically sourced from local emissions. With the increase of local dust emission, both total (coarse-mode) AODs are significantly increased from $0.14(0.08)$ to $0.26(0.20)$.

Furthermore, the column-mean PDR is also increased from $0.22 \pm 0.04$ to $0.25 \pm 0.03$. Correspondingly, the dust MEE is decreased from 0.56 to $0.45 \mathrm{~m}^{2} \mathrm{~g}^{-1}$ by increasing the coarse dust particles. The estimated dust mass loading is also significantly increased from 237,845 , to $870 \mu \mathrm{g} \mathrm{m}^{-2}$ with the maximum DMC of 430,500 , and $522 \mu \mathrm{g} \mathrm{m}^{-3}$ near the ground at the corresponding time. The separated dust $\mathrm{BC}$ is also smaller than the $\mathrm{ABC}$, which suggests that the contribution of anthropogenic pollution should not be ignored, especially for DMC evaluation.

\subsubsection{Average DMC Profile during Field Experiments}

To investigate the vertical distribution of DMC in Northwest China, we apply the MPL-based lidar-photometer method to all dust or polluted dust cases at Dunhuang_LZU, Minqin, and SACOL sites during the field experiments. The dust MEE is estimated by using the sun-photometer observations as described in Section 3.1. If the dust MEE is available and no cloud is double-checked by the MPL, the BC profiles of the dust particles can be effectively separated from the overall $\mathrm{ABC}$, and then the DEC and DMC profiles are estimated.

Figure 7a shows the average profiles of PDR for the DD, PD-I, and PD-II conditions. As it is seen, the column-mean PDR of DD is larger than that of the PD-I and PD-II. The vertical-resolved PDR is also slightly decreased by increasing the height and it becomes less than 0.31 for the DD condition. This suggests that the mixing between pure dust and anthropogenic pollution may occur at any height along with vertical transport of air mass. It also indicates that the dust classification based on $\mathrm{AE}_{440} 870$ and $\mathrm{CMF}$ only represents the average characteristics of the whole air column, and its heterogeneity in different heights must be carefully checked using active lidar detection.
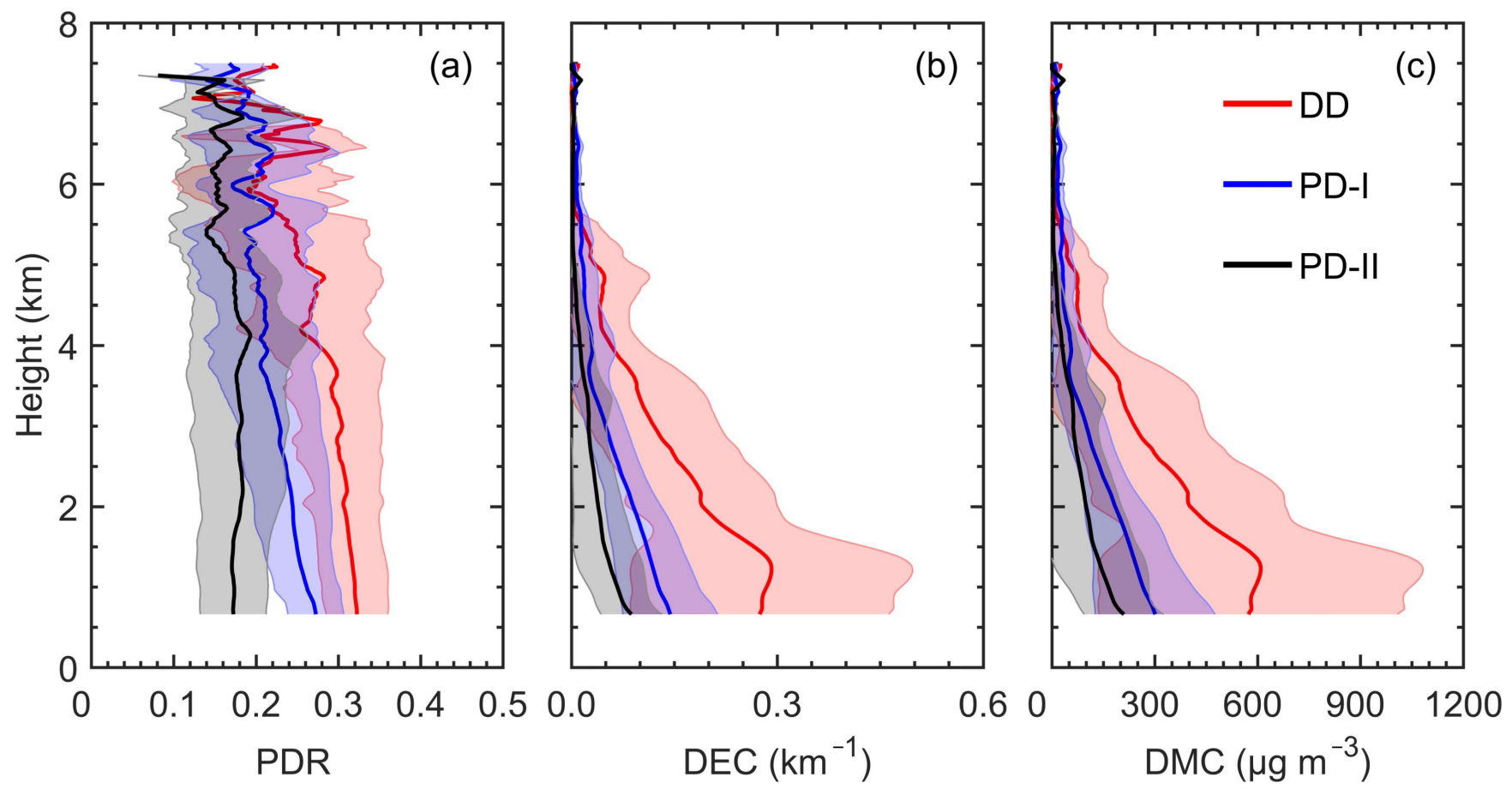

Figure 7. The average profiles of (a) PDR, (b) DEC, and (c) DMC during the field experiments in Dunhuang_LZU, Minqin, and SACOL for the DD, PD-I, and PD-II conditions. 
Figure $7 b, c$ shows the vertical distribution of DEC and DMC, respectively. Both DEC and DMC are decreased by increasing the height for the DD, PD-I, and PD-II conditions. The significant contribution of DEC and DMC can be observed under the $6 \mathrm{~km}$. The maxima of DEC and DMC are trapped in the planetary boundary layer under $2 \mathrm{~km}$. The integrated DEC (DOD) and DMC (dust mass loading) under $2 \mathrm{~km}$ is up to $0.43 \pm 0.27$ and $905 \pm 635 \mu \mathrm{g} \mathrm{m}^{-2}$ for the DD condition, on average, accounting for $57 \%$ of total DOD and $59 \%$ of total dust mass loading in the atmosphere, respectively. The bigger SD of DEC and DMC are mainly attributed as a large number of dust layers with different height and intensity are popular at three sites during the field experiments. They include not only the locally lofted or near-surface dust layer, but also long-range transported dust layer in the free troposphere. On average, the dust loading in Northwest China for the PD-I and PD-II conditions are significantly smaller than that for the DD condition.

\section{Discussion}

\subsection{Uncertainties of the DMC Retrieval}

The basic idea of the lidar-photometer method is to use the depolarization ratio observed by the lidar for separating non-spherical particles. This is then used to quantify the contribution of these particles into the lidar-derived profile of the overall ABC. The dust separation method using the PDR is a classic and well-established technique as described in $[80,91]$. The uncertainties in the aerosol optical properties and the retrieval error in the mass concentration are thoroughly investigated in previous research works, e.g., see, $[35,37,85,91]$.

The typical uncertainties in the MPL-based lidar-photometer method are caused by the following sources: (1) uncertainties in the basic lidar-based optical properties, e.g., the accuracy of the aerosol PDR and BC depend on the signal noise and the atmosphere parameters; (2) uncertainties in the assumption of non-dust $\left(\delta_{n d}\right)$ and dust $\left(\delta_{d}\right)$ depolarization ratios and the dust lidar ratio; (3) uncertainties in the estimation of the dust MEE based on sun-photometer observations. For well-detected desert dust layers, as shown in Zhou et al. [74], the overall uncertainty in the PDR derived by MPL is about $7-28 \%$ by relative variation of backscatter ratio and VDR. This is higher than that of $5-20 \%$ which is the uncertainty of multi-wavelength lidar as reported in Tesche et al. [91]. About 10-15\% of the uncertainties in the conversion of backscatter into the extinction coefficients are also introduced by the assumption of lidar ratio, the uncertainties of $10-25 \%$ in dust mass density of $2.6 \mathrm{~g} \mathrm{~m}^{-3}$, and $20-50 \%$ in dust MEE are also introduced in the retrieval of DMC, as shown in Ansmann et al. [85].

In this study, to reduce the effect of anthropogenic fine-mode pollutions on dust MEE for the DD, PD-I, and PD-II conditions, only the coarse-mode dust MEE was retrieved and used to estimate the mass concentration of all dust particles (fine + coarse). As shown in Ansmann et al. [89], the climatological representative MEE for fine-mode dust particles in Asia is about $1.42 \pm 0.32 \mathrm{~m}^{2} \mathrm{~g}^{-1}$, which is significantly greater than that of coarsemode dust. If we assumed the fine-mode fraction of 0.2 , coarse-mode and fine-mode dust MEE of 0.44 and $1.42 \mathrm{~m}^{2} \mathrm{~g}^{-1}$ respectively for the DD condition, the total DMC would be overestimated about $15.8 \%$ by the assumption of coarse-mode dust MEE. Therefore, the retrieval accuracy of DMC should be improved by distinguishing the fine-mode and coarse-mode dust particles and considering the change of dust MEE with the particle size, regardless of ground-based or satellite-based remote sensing technology.

Unlike the climatological mean MEE used in other studies [71,89], this study considered the variation of dust MEE with dust particle size in the estimation of the DMC. This partly offsets the retrieval error of the ABC and PDR from the single-detector MPL. The overall uncertainty in DMC estimation should be also about 30-60\% [85]. Note that the uncertainties may exceed $100 \%$ in cases with very large dust particles as shown in [37]. This is because of large uncertainties in the MEE, which is caused by the cut-off radii larger than $15 \mu \mathrm{m}$ in the AERONET data analysis scheme. 


\subsection{Uncertainty in DMC Caused by the Assumption of MEE}

As mentioned in Section 1, a fixed or linearly varying dust MEE is often used for estimating the DMC or dust flux on the transport routes based on passive or active satellite sensors $[22,26,28,29]$. Nevertheless, it has always been an open question to know the level of uncertainty introduced in the estimation of DMC by assuming the value of MEE. Although the MPL-based lidar-photometer method may have a high level of uncertainty in the estimation of $\mathrm{DMC}$, it also offers the opportunity of indirect evaluation of the DMC uncertainty.

A simple sensitivity test is designed, where we assume the dust MEE derived from real-time sun-photometer observations is accurate. This can be then used to obtain the real profile of DMC $\left(m_{r}\right)$ based on MPL-based lidar-photometer method. Similarly, the assumed dust MEE of 0.37 and $0.60 \mathrm{~m}^{2} \mathrm{~g}^{-1}$ is used to retrieve the assumed profile of DMC $\left(m_{a}\right)$. Then the relative error (RE) of DMC is obtained as the ratio of $\left(m_{a}-m_{r}\right) / m_{r}$. This test not only reflects the uncertainties introduced by the assumption of dust MEE but also offsets the uncertainties of the lidar-photometer method.

Figure 8 shows the statistical results of RE of DMC in Northwest China with the assumption of dust MEE of 0.37 and $0.60 \mathrm{~m}^{2} \mathrm{~g}^{-1}$ for the DD, PD-I, and PD-II conditions. As it is seen, assuming the dust MEE of $0.37 \mathrm{~m}^{2} \mathrm{~g}^{-1}$, overestimates the DMC by $20-40 \%$ on average, with the maximum overestimation in the DD and PD-I conditions. In contrast, setting the dust MEE to $0.60 \mathrm{~m}^{2} \mathrm{~g}^{-1}$ significantly underestimates the DMC by $15-30 \%$ on average, with the maximum underestimation in the PD-II condition.
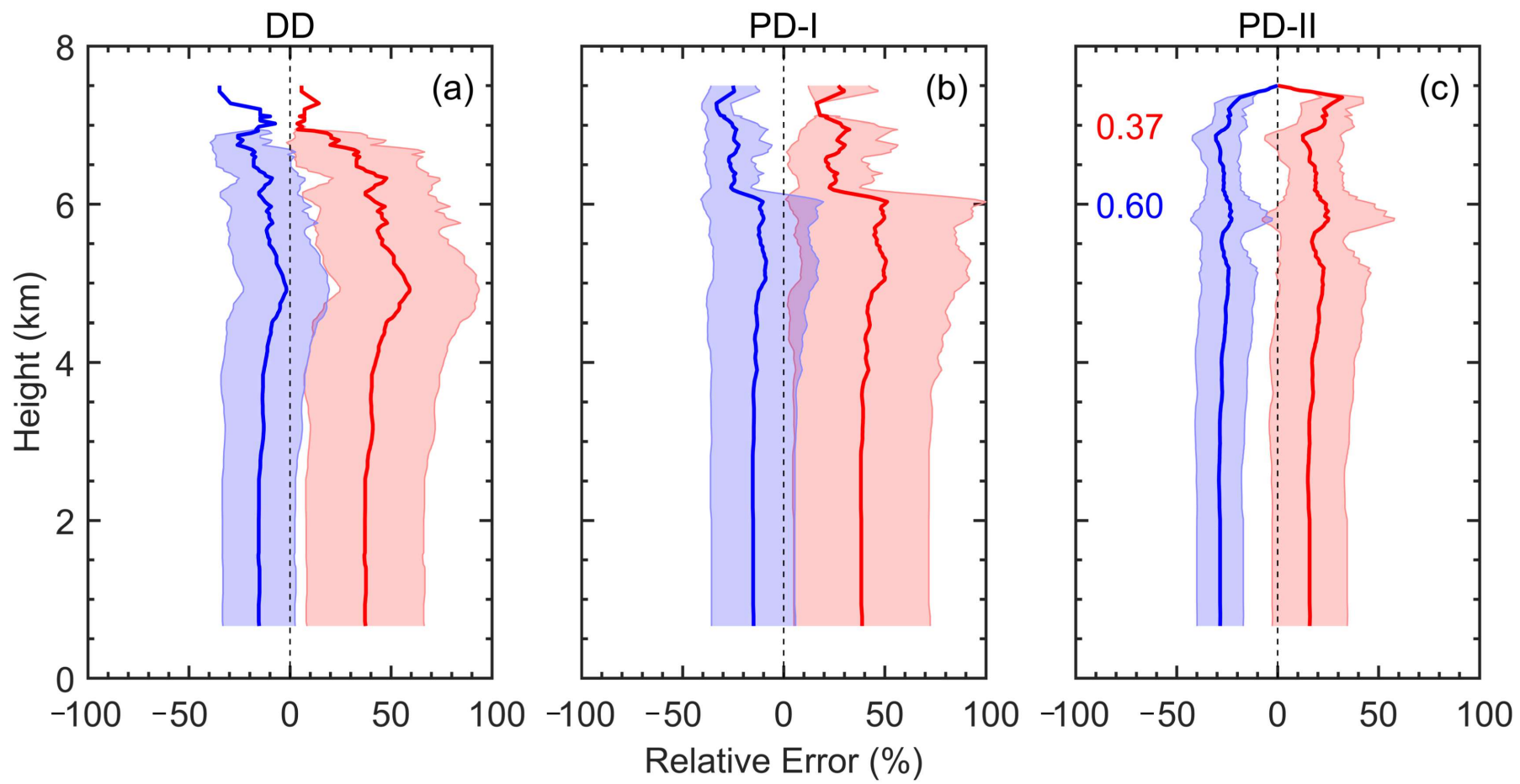

Figure 8. The vertical distribution of the relative error (RE) of the DMC introduced for the dust MEE of 0.37 (red) and 0.60 (blue) $\mathrm{m}^{2} \mathrm{~g}^{-1}$, respectively.

The uniform RE in the vertical direction is mainly due to the assumption of the same MEE throughout the dust layer. Therefore, the DMC retrieval uncertainties caused by the assumption of dust MEE cannot be simply ignored in satellite-based remote sensing. Hence, the change of MEE with the size of dust particles must be considered in the DMC estimation based on remote sensing technology. 


\section{Conclusions}

In this paper, the objective is to investigate the sources of uncertainties in the estimation of DMC based on satellite remote sensing. These sources include the mixing of mineral dust and anthropogenic pollutants, and assuming a fixed value for the dust MEE. For our investigations, we considered the classic and widely used ground-based lidar-photometer method. We further used the cloud-screened and quality-assured observations of MPL and AERONET sun-photometer in four intensive dust field experiments, and a permanent site in Northwest China. This data was then utilized for separating dust particles from anthropogenic pollution, deriving the real-time dust MEE, profiling the DMC, and evaluating the uncertainties in DMC of the estimation of dust MEE. The main achieved results are the following:

- Dust identification and separation using PDR is more effective than that of $\mathrm{AE}_{440-870 \text {. }}$ Pure mineral dust and polluted dust in Northwest China can also be well identified by $\mathrm{AE}_{440-870} \leq 0.2$ with $\mathrm{CMF} \geq 0.8$ and $0.2<\mathrm{AE}_{440-870} \leq 1.2$ with $\mathrm{CMF} \geq 0.4$ without lidar detection.

- $\quad$ The dust MEE derived from the AERONET sun-photometer is within the range of 0.30 to $0.60 \mathrm{~m}^{2} \mathrm{~g}^{-1}$, with the average and SD of $0.44 \pm 0.05,0.44 \pm 0.07$, and $0.41 \pm 0.08 \mathrm{~m}^{2}$ $\mathrm{g}^{-1}$ for the DD, PD-I, and PD-II conditions. The obtained results are also consistent with the in-situ observations by airborne and multi-wavelength lidar in Africa.

- There is a significant negative correlation between the dust MEE and dust CER, with $\mathrm{R}$ of $-0.94,-0.95$, and -0.86 for the DD, PD-I, and PD-II conditions. This suggests that the dust MEE is not a fixed value and it significantly varies with the size of the dust particles in different dust weather processes.

- The MPL-based lidar-photometer method is efficient for the continental aerosol mixtures consisting of dust and anthropogenic pollutants in Northwest China. This method strongly relies on accurate lidar observations of the PDR.

- The measurements of DMC indicated that the dust loading mainly occurred in the free troposphere $(<6 \mathrm{~km})$. The average of dust mass loading trapped in the planetary boundary layer under $2 \mathrm{~km}$ is up to $905 \pm 635 \mathrm{\mu g} \mathrm{m}^{-2}$ for the DD condition in the studied dust field experiments.

- With the assumption of dust MEE of 0.37 and $0.60 \mathrm{~m}^{2} \mathrm{~g}^{-1}$, the DMC in Northwest China is respectively overestimated by $20-40 \%$ and underestimated by $15-30 \%$. This suggests that the change of MEE with the size of dust particles must be considered in the estimation of DMC, regardless of ground-based or satellite-based remote sensing.

Author Contributions: Conceptualization, T.W. and J.H.; methodology, T.W. and W.H.; software, Y.H.; validation, T.W. and Y.H.; formal analysis, T.W., Y.H. and W.H.; investigation, T.W. and W.H.; data curation, T.W., T.Z. and H.X.; writing-original draft preparation, T.W. and W.H.; writingreview and editing, T.W., J.H., Y.H., Z.H. and J.B.; visualization, Y.H. and J.T.; supervision, J.H.; project administration, J.H. and T.W. All authors have read and agreed to the published version of the manuscript.

Funding: This research is jointly supported by the National Natural Science Foundation of China (41775022, 41521004), the Strategic Priority Research Program of Chinese Academy of Sciences (XDA2006010 301), and the Fundamental Research Funds for the Central Universities (lzujbky-2020-kb02).

Data Availability Statement: All AERONET observations can be freely downloaded from the homepage (https: / / aeronet.gsfc.nasa.gov/, accessed on 1 March 2021). The MPL data can be distributed on request (https: / / cliamte.lzu.edu.cn/, accessed on 1 March 2021). The ERA-interim data are obtained from ECMWF Integrated Forecasting System (https:/ / www.ecmwf.int/en/forecasts / datasets/browse-reanalysis-datasets, accessed on 1 March 2021). 
Acknowledgments: We are grateful to the principal investigators (Brent Holben, Si-Chee Tsay, Wu Zhang) and their staff for efforts in establishing and maintaining the instruments at AERONET sites used in this work. We would also like to express our special thanks to the great thoughts of the polarization lidar photometer networking (POLIPHON) method developed by Ansmann and his teams. We appreciate the GSFC/NASA AERONET group for processing the AERONET data. We would also like to thank three anonymous reviews for their constructive and insightful comments.

Conflicts of Interest: The authors declare no conflict of interest.

\section{References}

1. Li, Z.; Lau, W.K.M.; Ramanathan, V.; Wu, G.; Ding, Y.; Manoj, M.G.; Liu, J.; Qian, Y.; Li, J.; Zhou, T.; et al. Aerosol and monsoon climate interactions over Asia. Rev. Geophys. 2016, 54, 866-929. [CrossRef]

2. Huang, J.; Wang, T.; Wang, W.; Li, Z.; Yan, H. Climate effects of dust aerosols over East Asian arid and semiarid regions. J. Geophys. Res. Atmos. 2014, 119, 11398-311416. [CrossRef]

3. Wang, T.; Han, Y.; Huang, J.; Sun, M.; Jian, B.; Huang, Z.; Yan, H. Climatology of dust-forced radiative heating over the Tibetan Plateau and its surroundings. J. Geophys. Res. Atmos. 2020, 125, e2020JD032942. [CrossRef]

4. Huang, J.; Lin, B.; Minnis, P.; Wang, T.; Wang, X.; Hu, Y.; Yi, Y.; Ayers, J.K. Satellite-based assessment of possible dust aerosols semi-direct effect on cloud water path over East Asia. Geophys. Res. Lett. 2006, 33, L19802. [CrossRef]

5. Huang, J.; Minnis, P.; Lin, B.; Wang, T.; Yi, Y.; Hu, Y.; Sun-Mack, S.; Ayers, K. Possible influences of Asian dust aerosols on cloud properties and radiative forcing observed from MODIS and CERES. Geophys. Res. Lett. 2006, 33. [CrossRef]

6. Liu, Y.; Li, Y.; Huang, J.; Zhu, Q.; Wang, S. Attribution of the Tibetan Plateau to northern drought. Natl. Sci. Rev. 2020, 7, 489-492. [CrossRef]

7. Liu, Y.; Zhu, Q.; Huang, J.; Hua, S.; Jia, R. Impact of dust-polluted convective clouds over the Tibetan Plateau on downstream precipitation. Atmos. Environ. 2019, 209, 67-77. [CrossRef]

8. Yan, H.; Wang, T. Ten Years of Aerosol Effects on Single-Layer Overcast Clouds over the U.S. Southern Great Plains and the China Loess Plateau. Adv. Meteorol. 2020, 2020, 6719160. [CrossRef]

9. Mahowald, N.; Jickells, T.D.; Baker, A.R.; Artaxo, P.; Benitez-Nelson, C.R.; Bergametti, G.; Bond, T.C.; Chen, Y.; Cohen, D.D.; Herut, B.; et al. Global distribution of atmospheric phosphorus sources, concentrations and deposition rates, and anthropogenic impacts. Glob. Biogeochem. Cycles 2008, 22, GB4026. [CrossRef]

10. Yu, H.; Chin, M.; Yuan, T.; Bian, H.; Remer, L.A.; Prospero, J.M.; Omar, A.; Winker, D.; Yang, Y.; Zhang, Y.; et al. The fertilizing role of African dust in the Amazon rainforest: A first multiyear assessment based on data from Cloud-Aerosol Lidar and Infrared Pathfinder Satellite Observations. Geophys. Res. Lett. 2015, 42, 1984-1991. [CrossRef]

11. Tan, S.; Li, J.; Che, H.; Chen, B.; Wang, H. Transport of East Asian dust storms to the marginal seas of China and the southern North Pacific in spring 2010. Atmos. Environ. 2017, 148, 316-328. [CrossRef]

12. Prospero, J.M.; Barkley, A.E.; Gaston, C.J.; Gatineau, A.; Sansano, A.C.Y.; Panechou, K. Characterizing and Quantifying African Dust Transport and Deposition to South America: Implications for the Phosphorus Budget in the Amazon Basin. Glob. Biogeochem. Cycles 2020, 34. [CrossRef]

13. Prospero, J.M.; Collard, F.X.; Molinie, J.; Jeannot, A. Characterizing the annual cycle of African dust transport to the Caribbean Basin and South America and its impact on the environment and air quality. Glob. Biogeochem. Cycles 2014, 28, 757-773. [CrossRef]

14. Griffin, D.W. Atmospheric movement of microorganisms in clouds of desert dust and implications for human health. Clin. Microbiol. Rev. 2007, 20, 459-477. [CrossRef]

15. Shao, Y.; Wyrwoll, K.-H.; Chappell, A.; Huang, J.; Lin, Z.; McTainsh, G.H.; Mikami, M.; Tanaka, T.Y.; Wang, X.; Yoon, S. Dust cycle: An emerging core theme in Earth system science. Aeolian Res. 2011, 2, 181-204. [CrossRef]

16. Wang, T.; Tang, J.; Sun, M.; Liu, X.; Huang, Y.; Huang, J.; Han, Y.; Cheng, Y.; Huang, Z.; Li, J. Identifying a transport mechanism of dust aerosols over South Asia to the Tibetan Plateau: A case study. Sci. Total Environ. 2021, 758, 143714. [CrossRef] [PubMed]

17. Kim, D.; Chin, M.; Yu, H.; Diehl, T.; Tan, Q.; Kahn, R.A.; Tsigaridis, K.; Bauer, S.E.; Takemura, T.; Pozzoli, L.; et al. Sources, sinks, and transatlantic transport of North African dust aerosol: A multimodel analysis and comparison with remote sensing data. J. Geophys. Res. Atmos. 2014, 119, 6259-6277. [CrossRef]

18. Chen, S.; Huang, J.; Kang, L.; Wang, H.; Ma, X.; He, Y.; Yuan, T.; Yang, B.; Huang, Z.; Zhang, G. Emission, transport, and radiative effects of mineral dust from the Taklimakan and Gobi deserts: Comparison of measurements and model results. Atmos. Chem. Phys. 2017, 17, 2401-2421. [CrossRef]

19. Sarangi, C.; Qian, Y.; Rittger, K.; Leung, L.R.; Chand, D.; Bormann, K.J.; Painter, T.H. Dust dominates high-altitude snow darkening and melt over high-mountain Asia. Nat. Clim. Chang. 2020, 10, 1045-1051. [CrossRef]

20. Kok, J.F.; Ridley, D.A.; Zhou, Q.; Miller, R.L.; Zhao, C.; Heald, C.L.; Ward, D.S.; Albani, S.; Haustein, K. Integrative analysis of desert dust size and abundance suggests less dust climate cooling. Nat. Geosci. 2017, 10, 274-278. [CrossRef] [PubMed]

21. Huneeus, N.; Schulz, M.; Balkanski, Y.; Griesfeller, J.; Prospero, J.; Kinne, S.; Bauer, S.; Boucher, O.; Chin, M.; Dentener, F.; et al. Global dust model intercomparison in AeroCom phase I. Atmos. Chem. Phys. 2011, 11, 7781-7816. [CrossRef]

22. Kaufman, Y.J.; Koren, I.; Remer, L.A.; Tanre, D.; Ginoux, P.; Fan, S. Dust transport and deposition observed from the TerraModerate Resolution Imaging Spectroradiometer (MODIS) spacecraft over the Atlantic Ocean. J. Geophys. Res. Atmos. 2005, 110, D10S12. [CrossRef] 
23. Jin, S.; Ma, Y.; Zhang, M.; Gong, W.; Dubovik, O.; Liu, B.; Shi, Y.; Yang, C. Retrieval of $500 \mathrm{~m}$ Aerosol Optical Depths from MODIS Measurements over Urban Surfaces under Heavy Aerosol Loading Conditions in Winter. Remote Sens. 2019, 11, 2218. [CrossRef]

24. Zhang, M.X.; Zhao, C.; Cong, Z.Y.; Du, Q.Y.; Xu, M.Y.; Chen, Y.; Chen, M.; Li, R.; Fu, Y.F.; Zhong, L.; et al. Impact of topography on black carbon transport to the southern Tibetan Plateau during the pre-monsoon season and its climatic implication. Atmos. Chem. Phys. 2020, 20, 5923-5943. [CrossRef]

25. Tao, M.; Chen, L.; Wang, Z.; Wang, J.; Che, H.; Xu, X.; Wang, W.; Tao, J.; Zhu, H.; Hou, C. Evaluation of MODIS Deep Blue Aerosol Algorithm in Desert Region of East Asia: Ground Validation and Intercomparison. J. Geophys. Res. Atmos. 2017, 122, 10329-10340. [CrossRef]

26. Yu, H.; Chin, M.; Bian, H.; Yuan, T.; Prospero, J.M.; Omar, A.H.; Remer, L.A.; Winker, D.M.; Yang, Y.; Zhang, Y.; et al. Quantification of trans-Atlantic dust transport from seven-year (2007-2013) record of CALIPSO lidar measurements. Remote Sens. Environ. 2015, 159, 232-249. [CrossRef]

27. Ginoux, P.; Prospero, J.; Gill, T.; Hsu, N.; Zhao, M. Global-scale attribution of anthropogenic and natural dust sources and their emission rates based on MODIS Deep Blue aerosol products. Rev. Geophys. 2012, 50, RG3005. [CrossRef]

28. Huang, J.; Liu, J.; Chen, B.; Nasiri, S. Detection of anthropogenic dust using CALIPSO lidar measurements. Atmos. Chem. Phys. 2015, 15, 11653-11665. [CrossRef]

29. Yu, H.; Tan, Q.; Chin, M.; Remer, L.A.; Kahn, R.A.; Bian, H.; Kim, D.; Zhang, Z.; Yuan, T.; Omar, A.H.; et al. Estimates of African Dust Deposition Along the Trans-Atlantic Transit Using the Decadelong Record of Aerosol Measurements from CALIOP, MODIS, MISR, and IASI. J. Geophys. Res. Atmos. 2019, 124, 7975-7996. [CrossRef]

30. Liu, Z.; Winker, D.; Omar, A.; Vaughan, M.; Kar, J.; Trepte, C.; Hu, Y.; Schuster, G. Evaluation of CALIOP 532 nm aerosol optical depth over opaque water clouds. Atmos. Chem. Phys. 2015, 15, 1265-1288. [CrossRef]

31. Osborne, S.R.; Johnson, B.T.; Haywood, J.M.; Baran, A.J.; Harrison, M.A.J.; McConnell, C.L. Physical and optical properties of mineral dust aerosol during the Dust and Biomass-burning Experiment. J. Geophys. Res. Atmos. 2008, 113, D00C03. [CrossRef]

32. Johnson, B.T.; Osborne, S.R. Physical and optical properties of mineral dust aerosol measured by aircraft during the GERBILS campaign. Q. J. R. Meteorol. Soc. 2011, 137, 1117-1130. [CrossRef]

33. Weinzierl, B.; Petzold, A.; Esselborn, M.; Wirth, M.; Rasp, K.; Kandler, K.; Schuetz, L.; Koepke, P.; Fiebig, M. Airborne measurements of dust layer properties, particle size distribution and mixing state of Saharan dust during SAMUM 2006. Tellus B Chem. Phys. Meteorol. 2009, 61, 96-117. [CrossRef]

34. Müller, D.; Veselovskii, I.; Kolgotin, A.; Tesche, M.; Ansmann, A.; Dubovik, O. Vertical profiles of pure dust and mixed smoke-dust plumes inferred from inversion of multiwavelength Raman/polarization lidar data and comparison to AERONET retrievals and in situ observations. Appl. Opt. 2013, 52, 3178-3202. [CrossRef]

35. Mamouri, R.E.; Ansmann, A. Fine and coarse dust separation with polarization lidar. Atmos. Meas. Tech. 2014, 7, $3717-3735$. [CrossRef]

36. Maring, H.; Savoie, D.L.; Izaguirre, M.A.; Custals, L.; Reid, J.S. Mineral dust aerosol size distribution change during atmospheric transport. J. Geophys. Res. Atmos. 2003, 108, 8592. [CrossRef]

37. Ansmann, A.; Tesche, M.; Seifert, P.; Gross, S.; Freudenthaler, V.; Apituley, A.; Wilson, K.M.; Serikov, I.; Linne, H.; Heinold, B.; et al. Ash and fine-mode particle mass profiles from EARLINET-AERONET observations over central Europe after the eruptions of the Eyjafjallajokull volcano in 2010. J. Geophys. Res. Atmos. 2011, 116, D00U02. [CrossRef]

38. Wagner, J.; Ansmann, A.; Wandinger, U.; Seifert, P.; Schwarz, A.; Tesche, M.; Chaikovsky, A.; Dubovik, O. Evaluation of the Lidar/Radiometer Inversion Code (LIRIC) to determine microphysical properties of volcanic and desert dust. Atmos. Meas. Tech. 2013, 6, 1707-1724. [CrossRef]

39. Nemuc, A.; Vasilescu, J.; Talianu, C.; Belegante, L.; Nicolae, D. Assessment of aerosol's mass concentrations from measured linear particle depolarization ratio (vertically resolved) and simulations. Atmos. Meas. Tech. 2013, 6, 3243-3255. [CrossRef]

40. Mamouri, R.E.; Ansmann, A. Potential of polarization/Raman lidar to separate fine dust, coarse dust, maritime, and anthropogenic aerosol profiles. Atmos. Meas. Tech. 2017, 10, 3403-3427. [CrossRef]

41. Huebert, B.J.; Bates, T.; Russell, P.B.; Shi, G.Y.; Kim, Y.J.; Kawamura, K.; Carmichael, G.; Nakajima, T. An overview of ACE-Asia: Strategies for quantifying the relationships between Asian aerosols and their climatic impacts. J. Geophys. Res. Atmos. 2003, 108, 8633. [CrossRef]

42. Mikami, M.; Shi, G.Y.; Uno, I.; Yabuki, S.; Iwasaka, Y.; Yasui, M.; Aoki, T.; Tanaka, T.Y.; Kurosaki, Y.; Masuda, K.; et al. Aeolian dust experiment on climate impact: An overview of Japan-China joint project ADEC. Glob. Planet. Chang. 2006, 52, 142-172. [CrossRef]

43. Huang, J.; Minnis, P.; Chen, B.; Huang, Z.; Liu, Z.; Zhao, Q.; Yi, Y.; Ayers, J. Long-range transport and vertical structure of Asian dust from CALIPSO and surface measurements during PACDEX. J. Geophys. Res. Atmos. 2008, 113, D23212. [CrossRef]

44. Li, Z.; Li, C.; Chen, H.; Tsay, S.C.; Holben, B.; Huang, J.; Li, B.; Maring, H.; Qian, Y.; Shi, G.; et al. East Asian Studies of Tropospheric Aerosols and their Impact on Regional Climate (EAST-AIRC): An overview. J. Geophys. Res. Atmos. 2011, 116, D00K34. [CrossRef]

45. Holben, B.N.; Eck, T.F.; Slutsker, I.; Tanre, D.; Buis, J.P.; Setzer, A.; Vermote, E.; Reagan, J.A.; Kaufman, Y.J.; Nakajima, T.; et al. AERONET-A federated instrument network and data archive for aerosol characterization. Remote Sens. Environ. 1998, 66, 1-16. [CrossRef] 
46. Eck, T.F.; Holben, B.N.; Dubovik, O.; Smirnov, A.; Goloub, P.; Chen, H.B.; Chatenet, B.; Gomes, L.; Zhang, X.Y.; Tsay, S.C.; et al. Columnar aerosol optical properties at AERONET sites in central eastern Asia and aerosol transport to the tropical mid-Pacific. J. Geophys. Res. Atmos. 2005, 110, D06202. [CrossRef]

47. Takamura, T.; Nakajima, T. Overview of SKYNET and its activities. Pure Appl. Opt. 2004, 37, 3303-3308.

48. Nakajima, T.; Yoon, S.C.; Ramanathan, V.; Shi, G.Y.; Takemura, T.; Higurashi, A.; Takamura, T.; Aoki, K.; Sohn, B.J.; Kim, S.W.; et al. Overview of the Atmospheric Brown Cloud East Asian Regional Experiment 2005 and a study of the aerosol direct radiative forcing in east Asia. J. Geophys. Res. Atmos. 2007, 112, D24S91. [CrossRef]

49. Che, H.; Zhang, X.; Chen, H.; Damiri, B.; Goloub, P.; Li, Z.; Zhang, X.; Wei, Y.; Zhou, H.; Dong, F.; et al. Instrument calibration and aerosol optical depth validation of the China Aerosol Remote Sensing Network. J. Geophys. Res. Atmos. 2009, 114 , D03206. [CrossRef]

50. Che, H.; Zhang, X.Y.; Xia, X.; Goloub, P.; Holben, B.; Zhao, H.; Wang, Y.; Zhang, X.C.; Wang, H.; Blarel, L.; et al. Ground-based aerosol climatology of China: Aerosol optical depths from the China Aerosol Remote Sensing Network (CARSNET) $2002-2013$. Atmos. Chem. Phys. 2015, 15, 7619-7652. [CrossRef]

51. Bi, J.; Huang, J.; Shi, J.; Hu, Z.; Zhou, T.; Zhang, G.; Huang, Z.; Wang, X.; Jin, H. Measurement of scattering and absorption properties of dust aerosol in a Gobi farmland region of northwestern China-A potential anthropogenic influence. Atmos. Chem. Phys. 2017, 17, 7775-7792. [CrossRef]

52. Arimoto, R.; Zhang, X.Y.; Huebert, B.J.; Kang, C.H.; Savoie, D.L.; Prospero, J.M.; Sage, S.K.; Schloesslin, C.A.; Khaing, H.M.; Oh, S.N. Chemical composition of atmospheric aerosols from Zhenbeitai, China, and Gosan, South Korea, during ACE-Asia. J. Geophys. Res. Atmos. 2004, 109, D19S04. [CrossRef]

53. Xu, J.; Bergin, M.H.; Greenwald, R.; Schauer, J.J.; Shafer, M.M.; Jaffrezo, J.L.; Aymoz, G. Aerosol chemical, physical, and radiative characteristics near a desert source region of northwest China during ACE-Asia. J. Geophys. Res. Atmos. 2004, 109, D19S03. [CrossRef]

54. Wang, T.; Huang, J. A method for estimating optical properties of dusty cloud. Chin. Opt. Lett. 2009, 7, 368-372. [CrossRef]

55. Huang, Z.; Huang, J.; Bi, J.; Wang, G.; Wang, W.; Fu, Q.; Li, Z.; Tsay, S.-C.; Shi, J. Dust aerosol vertical structure measurements using three MPL lidars during 2008 China-U.S. joint dust field experiment. J. Geophys. Res. Atmos. 2010, 115. [CrossRef]

56. Bi, J.; Huang, J.; Fu, Q.; Ge, J.; Shi, J.; Zhou, T.; Zhang, W. Field measurement of clear-sky solar irradiance in Badain Jaran Desert of Northwestern China. J. Quant. Spectrosc. Radiat. Transf. 2013, 122, 194-207. [CrossRef]

57. Wang, X.; Wen, H.; Shi, J.; Bi, J.; Huang, Z.; Zhang, B.; Zhou, T.; Fu, K.; Chen, Q.; Xin, J. Optical and microphysical properties of natural mineral dust and anthropogenic soil dust near dust source regions over northwestern China. Atmos. Chem. Phys. 2018, 18, 2119-2138. [CrossRef]

58. Tian, P.; Zhang, L.; Ma, J.; Tang, K.; Xu, L.; Wang, Y.; Cao, X.; Liang, J.; Ji, Y.; Jiang, J.; et al. Radiative absorption enhancement of dust mixed with anthropogenic pollution over East Asia. Atmos. Chem. Phys. 2018, 18, 7815-7825. [CrossRef]

59. Zhang, X.; Arimoto, R.; An, Z. Dust emission from Chinese desert sources linked to variations in atmospheric circulation. J. Geophys. Res. Atmos. 1997, 102, 28041-28047. [CrossRef]

60. Zhang, X.; Zhang, G.; Zhu, G.; Zhang, D.; An, Z.; Chen, T.; Huang, X. Elemental tracers for Chinese source dust. Sci. China Ser. D Earth Sci. 1996, 39, 512-521.

61. Huang, J.P.; Zhang, W.; Zuo, J.Q.; Bi, J.R.; Shi, J.S.; Wang, X.; Chang, Z.L.; Huang, Z.W.; Yang, S.; Zhang, B.D.; et al. An Overview of the Semi-arid Climate and Environment Research Observatory over the Loess Plateau. Adv. Atmos. Sci. 2008, 25, 906-921. [CrossRef]

62. Campbell, J.R.; Hlavka, D.L.; Welton, E.J.; Flynn, C.J.; Turner, D.D.; Spinhirne, J.D.; Scott, V.S.; Hwang, I.H. Full-time, eye-safe cloud and aerosol lidar observation at atmospheric radiation measurement program sites: Instruments and data processing J. Atmos. Ocean. Technol. 2002, 19, 431-442. [CrossRef]

63. Xie, H.; Zhou, T.; Fu, Q.; Huang, J.; Huang, Z.; Bi, J.; Shi, J.; Zhang, B.; Ge, J. Automated detection of cloud and aerosol features with SACOL micro-pulse lidar in northwest China. Opt. Express 2017, 25, 30732-30753. [CrossRef]

64. O'Neill, N.T.; Eck, T.F.; Smirnov, A.; Holben, B.N.; Thulasiraman, S. Spectral discrimination of coarse and fine mode optical depth. J. Geophys. Res. Atmos. 2003, 108, 4559. [CrossRef]

65. Dubovik, O.; Sinyuk, A.; Lapyonok, T.; Holben, B.N.; Mishchenko, M.; Yang, P.; Eck, T.F.; Volten, H.; Munoz, O.; Veihelmann, B.; et al. Application of spheroid models to account for aerosol particle nonsphericity in remote sensing of desert dust. J. Geophys. Res. Atmos. 2006, 111, D11208. [CrossRef]

66. Dubovik, O.; Holben, B.; Eck, T.F.; Smirnov, A.; Kaufman, Y.J.; King, M.D.; Tanre, D.; Slutsker, I. Variability of absorption and optical properties of key aerosol types observed in worldwide locations. J. Geophys. Res. Atmos. 2002, 59, 590-608. [CrossRef]

67. Müller, D.; Weinzierl, B.; Petzold, A.; Kandler, K.; Ansmann, A.; Muller, T.; Tesche, M.; Freudenthaler, V.; Esselborn, M.; Heese, B.; et al. Mineral dust observed with AERONET Sun photometer, Raman lidar, and in situ instruments during SAMUM 2006: Shape-independent particle properties. J. Geophys. Res. Atmos. 2010, 115, D11207. [CrossRef]

68. Ginoux, P.; Chin, M.; Tegen, I.; Prospero, J.M.; Holben, B.; Dubovik, O.; Lin, S.J. Sources and distributions of dust aerosols simulated with the GOCART model. J. Geophys. Res. Atmos. 2001, 106, 20255-20273. [CrossRef]

69. Hess, M.; Koepke, P.; Schult, I. Optical properties of aerosols and clouds: The software package OPAC. Bull. Am. Meteorol. Soc. 1998, 79, 831-844. [CrossRef] 
70. Gasteiger, J.; Gross, S.; Freudenthaler, V.; Wiegner, M. Volcanic ash from Iceland over Munich: Mass concentration retrieved from ground-based remote sensing measurements. Atmos. Chem. Phys. 2011, 11, 2209-2223. [CrossRef]

71. Cordoba-Jabonero, C.; Sicard, M.; Ansmann, A.; del Aguila, A.; Baars, H. Separation of the optical and mass features of particle components in different aerosol mixtures by using POLIPHON retrievals in synergy with continuous polarized Micro-Pulse Lidar (P-MPL) measurements. Atmos. Meas. Tech. 2018, 11, 4775-4795. [CrossRef]

72. Flynn, C.; Mendoza, A.; Zheng, Y.; Mathur, S. Novel polarization-sensitive micropulse lidar measurement technique. Opt. Express 2007, 15, 2785-2790. [CrossRef]

73. Dee, D.P.; Uppala, S.M.; Simmons, A.J.; Berrisford, P.; Poli, P.; Kobayashi, S.; Andrae, U.; Balmaseda, M.A.; Balsamo, G.; Bauer, P.; et al. The ERA-Interim reanalysis: Configuration and performance of the data assimilation system. Q. J. R. Meteorol. Soc. 2011, 137, 553-597. [CrossRef]

74. Zhou, T.; Xie, H.; Bi, J.; Huang, Z.; Huang, J.; Shi, J.; Zhang, B.; Zhang, W. Lidar Measurements of Dust Aerosols during Three Field Campaigns in 2010, 2011 and 2012 over Northwestern China. Atmosphere 2018, 9, 173. [CrossRef]

75. Hayasaka, T.; Satake, S.; Shimizu, A.; Sugimoto, N.; Matsui, I.; Aoki, K.; Muraji, Y. Vertical distribution and optical properties of aerosols observed over Japan during the Atmospheric Brown Clouds-East Asia Regional Experiment 2005. J. Geophys. Res. Atmos. 2007, 112, D22S35. [CrossRef]

76. Freudenthaler, V.; Esselborn, M.; Wiegner, M.; Heese, B.; Tesche, M.; Ansmann, A.; Mueller, D.; Althausen, D.; Wirth, M.; Fix, A.; et al. Depolarization ratio profiling at several wavelengths in pure Saharan dust during SAMUM 2006. Tellus B Chem. Phys. Meteorol. 2009, 61, 165-179. [CrossRef]

77. Groß, S.; Tesche, M.; Freudenthaler, V.; Toledano, C.; Wiegner, M.; Ansmann, A.; Althausen, D.; Seefeldner, M. Characterization of Saharan dust, marine aerosols and mixtures of biomass-burning aerosols and dust by means of multi-wavelength depolarization and Raman lidar measurements during SAMUM 2. Tellus B Chem. Phys. Meteorol. 2011, 63, 706-724. [CrossRef]

78. Wiegner, M.; Gross, S.; Freudenthaler, V.; Schnell, F.; Gasteiger, J. The May/June 2008 Saharan dust event over Munich: Intensive aerosol parameters from lidar measurements. J. Geophys. Res. Atmos. 2011, 116, D23213. [CrossRef]

79. Shimizu, A.; Sugimoto, N.; Matsui, I.; Arao, K.; Uno, I.; Murayama, T.; Kagawa, N.; Aoki, K.; Uchiyama, A.; Yamazaki, A. Continuous observations of Asian dust and other aerosols by polarization lidars in China and Japan during ACE-Asia. J. Geophys. Res. Atmos. 2004, 109, D19S17. [CrossRef]

80. Sugimoto, N.; Uno, I.; Nishikawa, M.; Shimizu, A.; Matsui, I.; Dong, X.; Chen, Y.; Quan, H. Record heavy Asian dust in Beijing in 2002: Observations and model analysis of recent events. Geophys. Res. Lett. 2003, 30, 1640. [CrossRef]

81. Hu, Q.; Wang, H.; Goloub, P.; Li, Z.; Veselovskii, I.; Podvin, T.; Li, K.; Korenskiy, M. The characterization of Taklamakan dust properties using a multiwavelength Raman polarization lidar in Kashi, China. Atmos. Chem. Phys. 2020, 20, 13817-13834. [CrossRef]

82. Hofer, J.; Ansmann, A.; Althausen, D.; Engelmann, R.; Baars, H.; Fomba, K.W.; Wandinger, U.; Abdullaev, S.F.; Makhmudov, A.N. Optical properties of Central Asian aerosol relevant for spaceborne lidar applications and aerosol typing at 355 and $532 \mathrm{~nm}$. Atmos. Chem. Phys. 2020, 20, 9265-9280. [CrossRef]

83. Kim, M.-H.; Omar, A.H.; Tackett, J.L.; Vaughan, M.A.; Winker, D.M.; Trepte, C.R.; Hu, Y.; Liu, Z.; Poole, L.R.; Pitts, M.C.; et al. The CALIPSO version 4 automated aerosol classification and lidar ratio selection algorithm. Atmos. Meas. Tech. 2018, 11, 6107-6135. [CrossRef]

84. Córdoba-Jabonero, C.; Andrey-Andrés, J.; Gómez, L.; Adame, J.A.; Sorribas, M.; Navarro-Comas, M.; Puentedura, O.; Cuevas, E.; Gil-Ojeda, M. Vertical mass impact and features of Saharan dust intrusions derived from ground-based remote sensing in synergy with airborne in-situ measurements. Atmos. Environ. 2016, 142, 420-429. [CrossRef]

85. Ansmann, A.; Seifert, P.; Tesche, M.; Wandinger, U. Profiling of fine and coarse particle mass: Case studies of Saharan dust and Eyjafjallajökull/Grimsvötn volcanic plumes. Atmos. Chem. Phys. 2012, 12, 9399-9415. [CrossRef]

86. Burgos, M.A.; Mateos, D.; Cachorro, V.E.; Toledano, C.; de Frutos, A.M. Aerosol properties of mineral dust and its mixtures in a regional background of north-central Iberian Peninsula. Sci. Total Environ. 2016, 572, 1005-1019. [CrossRef] [PubMed]

87. Wang, T.; Chen, Y.; Gan, Z.; Han, Y.; Li, J.; Huang, J. Assessment of dominating aerosol properties and their long-term trend in the Pan-Third Pole region: A study with 10-year multi-sensor measurements. Atmos. Environ. 2020, 239, 117738. [CrossRef]

88. Bi, J.; Huang, J.; Holben, B.; Zhang, G. Comparison of key absorption and optical properties between pure and transported anthropogenic dust over East and Central Asia. Atmos. Chem. Phys. 2016, 16, 15501-15516. [CrossRef]

89. Ansmann, A.; Mamouri, R.E.; Hofer, J.; Baars, H.; Althausen, D.; Abdullaev, S.F. Dust mass, cloud condensation nuclei, and ice-nucleating particle profiling with polarization lidar: Updated POLIPHON conversion factors from global AERONET analysis. Atmos. Meas. Tech. 2019, 12, 4849-4865. [CrossRef]

90. Chen, G.; Ziemba, L.D.; Chu, D.A.; Thornhill, K.L.; Schuster, G.L.; Winstead, E.L.; Diskin, G.S.; Ferrare, R.A.; Burton, S.P.; Ismail, S.; et al. Observations of Saharan dust microphysical and optical properties from the Eastern Atlantic during NAMMA airborne field campaign. Atmos. Chem. Phys. 2011, 11, 723-740. [CrossRef]

91. Tesche, M.; Ansmann, A.; Muller, D.; Althausen, D.; Engelmann, R.; Freudenthaler, V.; Gross, S. Vertically resolved separation of dust and smoke over Cape Verde using multiwavelength Raman and polarization lidars during Saharan Mineral Dust Experiment 2008. J. Geophys. Res. Atmos. 2009, 114, D13202. [CrossRef] 